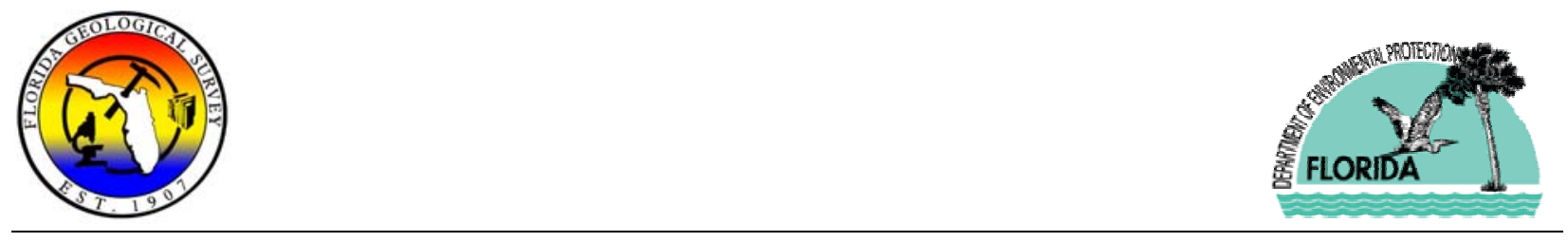

\title{
WEKIVA AQUIFER VULNERABILITY ASSESSMENT
}

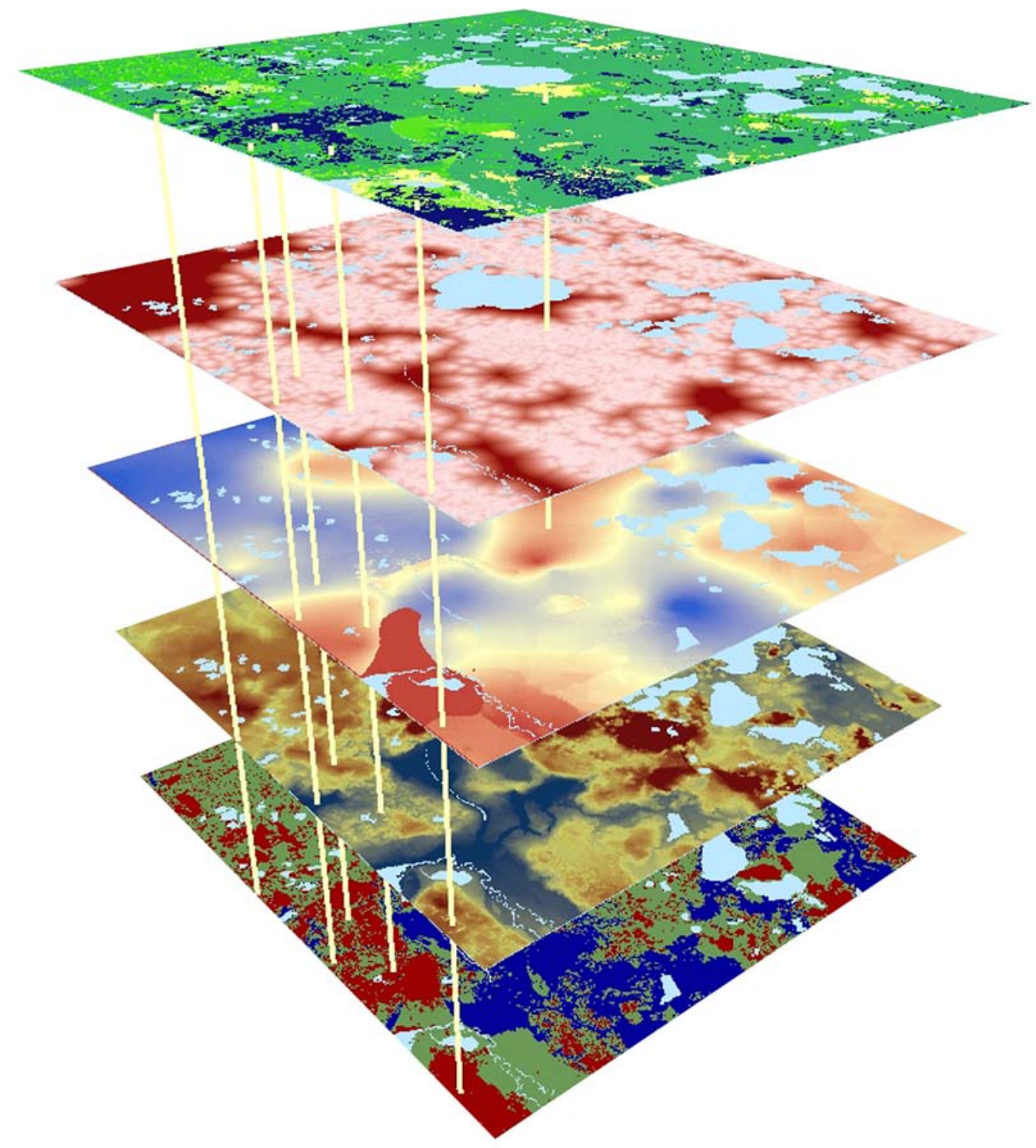

FLORIDA GEOLOGICAL SURVEY REPORT OF INVESTIGATION 104 
STATE OF FLORIDA

DEPARTMENT OF ENVIRONMENTAL PROTECTION

Colleen M. Castille, Secretary

\section{DIVISION OF RESOURCE ASSESSMENT AND MANAGEMENT \\ Edwin J. Conklin, Director}

\section{FLORIDA GEOLOGICAL SURVEY}

Walter Schmidt, State Geologist and Chief

Report of Investigation 104

WEKIVA AQUIFER VULNERABILITY ASSESSMENT

By

James R. Cichon, Alan E. Baker, Alex R. Wood, and Jonathan D. Arthur

Published for the

FLORIDA GEOLOGICAL SURVEY

Tallahassee, Florida

2005 
Printed for the Florida Geological Survey

Tallahassee 2005

ISSN 0160-0931 


\section{PREFACE}

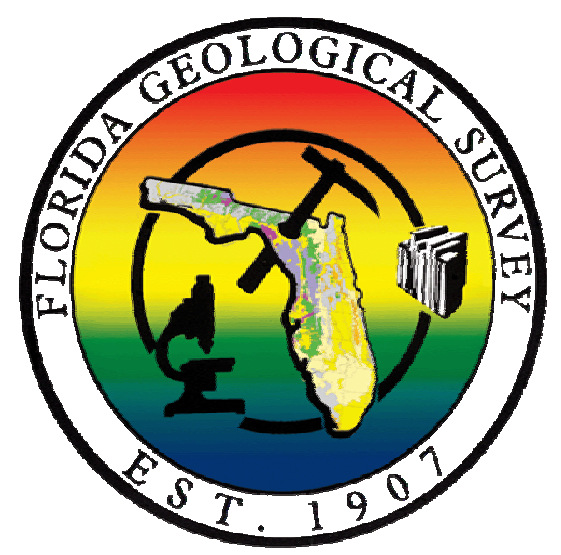

\section{FLORIDA GEOLOGICAL SURVEY}

\section{Tallahassee, Florida}

2005

The Florida Geological Survey (FGS), Division of Resource Assessment and Management, Department of Environmental Protection, is publishing as Report of Investigation No. 104, Wekiva Aquifer Vulnerability Assessment, authored by James R. Cichon, Alan E. Baker, Alex R. Wood, and Jonathan D. Arthur, all staff of the FGS.

This publication is a localized offshoot of the state-wide Florida Aquifer Vulnerability Assessment project (a Bulletin of the Florida Geological Survey, in press). Unbiased and credible scientific assessment of the potential vulnerability of our ground water aquifers to contamination and other surface modifications is critical to the future sustainability of Florida's environment. State, regional, county and local governmental agencies, as well as private land owners and the public will find this information useful in support of informed land-use planning and natural resource conservation and preservation decisions.

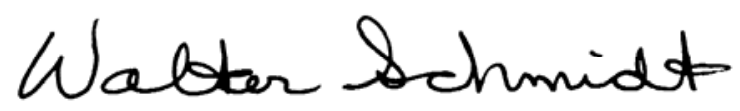

Walter Schmidt, Ph.D., P.G.

State Geologist \& Chief

Florida Geological Survey 


\section{TABLE OF CONTENTS}

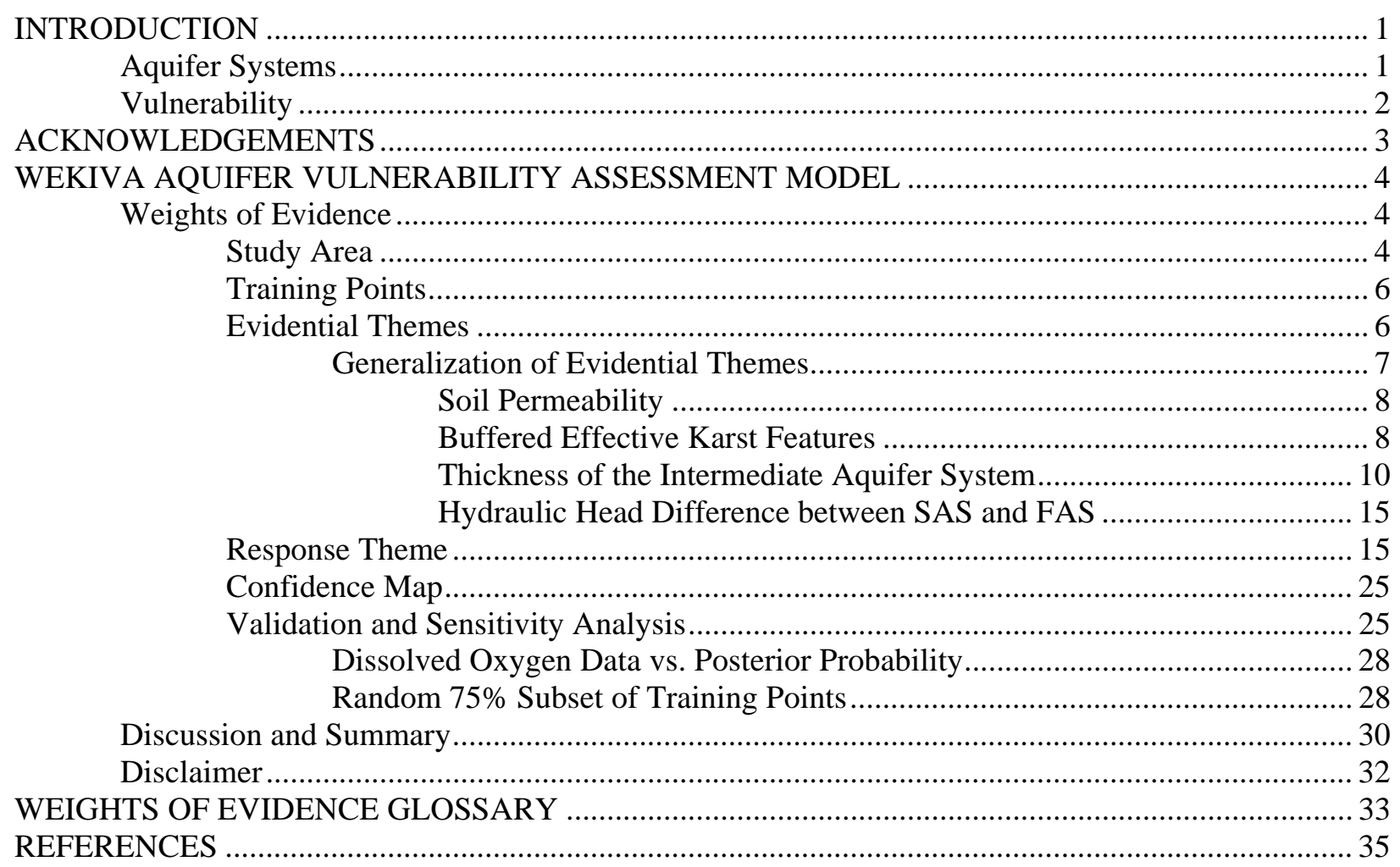

\section{FIGURES}

1. Hydrogeologic conceptual model of the Wekiva study area ............................................................

2. Extent of the WAVA study area and training point set developed based on dissolved oxygen .............. 5

3. Soil permeability map of the WAVA study area ............................................................................... 9

4. Soil permeability values (in/hr) plotted against contrast values calculated using WofE ........................ 10

5. Map showing binary generalization of the soil permeability evidential theme. .................................... 11

6. Closed topographic depressions underlain by less than 100 feet $(30.5 \mathrm{~m})$ of FAS overburden. ............. 12

7. Map showing binary generalization of the buffered effective karst features evidential theme. ..............13

8. Thickness grid of IAS (in feet) and the distribution of wells used ..................................................... 14

9. Map showing binary generalization of the IAS thickness evidential theme .......................................16

10. Hydraulic head difference between the SAS and the FAS potentiometric surface..............................17

11. Map showing binary generalization of the hydraulic head difference evidential theme....................... 18

12. Relative vulnerability of the FAS FAVA model................................................................................ 19

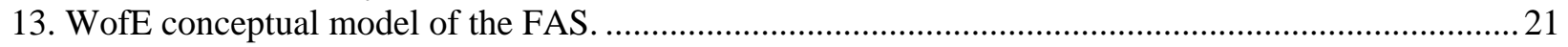

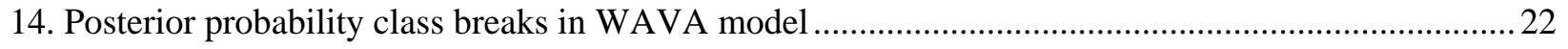

15. Relative vulnerability predicted by the WAVA model for the FAS .....................................................2

16. Relative vulnerability predicted by the FAS WAVA model showing hydrography.............................2.

17. Relative vulnerability of the WAVA model showing missing soil permeability data..........................26

18. Distribution of confidence values calculated for WAVA response theme. .........................................2

19. Posterior probability vs. dissolved oxygen median concentration values..........................................28

20. Relative vulnerability predicted by the WAVA model using a subset of training point data ................ 30 


\section{TABLES}

1. Test values calculated in WofE and their respective studentized T values............................................ 7

2. WofE final output table listing weights calculated for each evidential theme....................................22

3. Cross-tabulation matrix of the WAVA response theme versus the 75\% subset response theme ...........29

4. Kappa coefficient values and associated interpretation (Landis and Koch, 1977). ..............................29 


\title{
WEKIVA AQUIFER VULNERABILITY ASSESSMENT
}

\author{
By \\ James R. Cichon, Alan E. Baker, P.G. 2324, Alex R. Wood, and Jonathan D. Arthur, P.G. 1149
}

\section{INTRODUCTION}

The Floridan Aquifer System is among the most vast and vulnerable hydrogeologic resources in the nation. A remarkable $90 \%$ of Florida's drinking water originates from these ground-water resources (Berndt et al., 1998). More than 700 springs are known to exist in Florida, allowing a unique window into the aquifer systems (Scott et al., 2004). These springs have long been a resource for recreation and fresh water. Protection of Florida's springs becomes an increasingly important issue as the population of Florida continues to grow at a rate of almost 900 people per day (U.S. Census, 2005). As a result, pressures on these unique natural resources are intensifying.

It is important to note that water quality of Florida's springs is a reflection of the condition of the surrounding ground-water system and not just an indication of individual spring health. Springsheds, or the spring's area of ground-water contribution, must also be taken into consideration for any vulnerability assessment if proper protection of the spring itself is to take place. An assessment of the vulnerability of the ground water, which includes the springshed, can therefore be an important tool for decision making, development of rules or policies regarding environmental conservation, protection, growth management, and land-use planning. To fully understand the relationship between ground water and vulnerability, an understanding of the aquifer systems present in the study area is needed.

\section{Aquifer Systems}

The hydrogeologic framework of the Wekiva study area is comprised of three aquifer systems: the Surficial Aquifer System (SAS), the Intermediate Aquifer System (IAS) and the FAS. According to Florida Geological Survey Special Publication No. 28 (Southeastern Geological Society, 1986), the Surficial Aquifer System is "the permeable hydrogeologic unit contiguous with land surface that is comprised principally of unconsolidated to poorly indurated clastic deposits. It also includes wellindurated carbonate rocks...” that are not part of the FAS.

The intermediate aquifer system/intermediate confining unit consists of highly-variable siliciclastic and carbonate deposits that are relatively low-permeability, fine-grained sediments and collectively retard the exchange of water between the overlying SAS and the underlying FAS. The term "intermediate confining unit" applies to those areas where this unit yields little to no water, whereas the term "intermediate aquifer system" applies to those areas where one or more low to moderate-yielding aquifers occur. Special Publication No. 28 (Southeastern Geological Society, 1986) is currently under revision by the Florida Geological Survey (FGS), and the forthcoming update suggests the use of the term "Intermediate Aquifer System" for this entire unit. Moreover, the revision calls for the elimination of the use of "intermediate confining unit." Instead, the "intermediate confining unit" is considered to be confining beds within the IAS. This newer convention currently under review is hereby adopted in this report.

The FAS is comprised of a thick carbonate sequence of rocks that collectively function as a regional water-yielding hydraulic unit. Where overlain by the IAS, the FAS is confined; however, sinkholes that 


\section{FLORIDA GEOLOGICAL SURVEY}

breach the IAS can provide direct pathways for surface water to enter the FAS (Figure 1). Ground water also recharges the FAS by infiltration through overlying sediments of the IAS or SAS. In areas where the FAS is directly overlain by the SAS, the FAS may or may not contain ground water under confined conditions, depending on the thickness and extent of low permeability material at the base of the Surficial Aquifer System (Southeastern Geological Society, 1986).

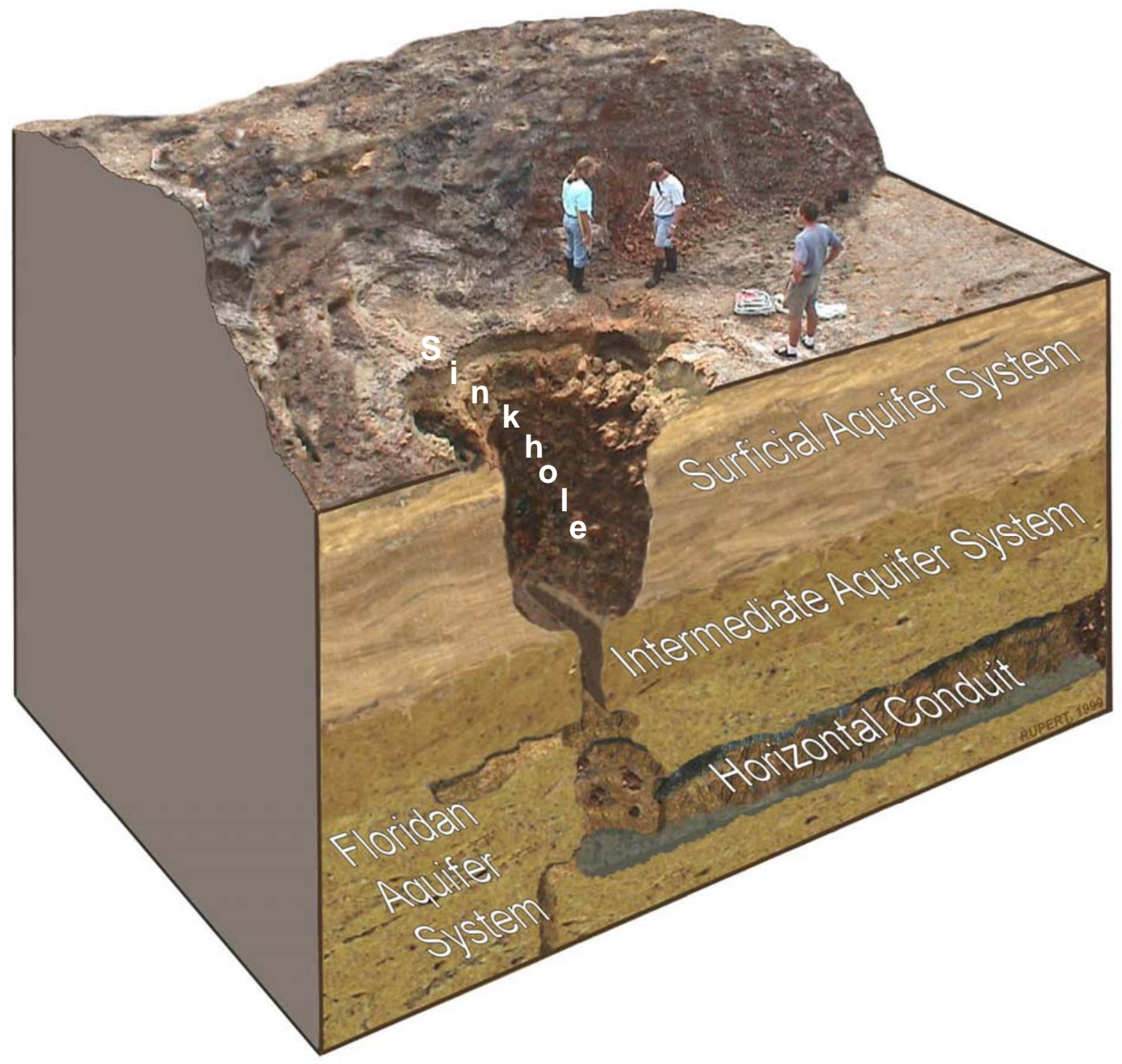

Figure 1. Hydrogeologic conceptual model of the Wekiva study area depicting the major aquifer systems and karst features.

\section{Vulnerability}

Due to Florida's unique hydrogeologic setting, all of Florida's ground water is vulnerable to contamination. In fact, this statement, in a more broad sense, is considered the "First Law of Ground Water Vulnerability" by the National Research Council (NRC, 1993) which states: "All ground water is 
REPORT OF INVESTIGATION NO. 104

vulnerable." Furthermore, the NRC defines the phrase "ground-water vulnerability to contamination" as the tendency or likelihood for contaminants to reach a specified position in the ground-water system after introduction at some location above the uppermost aquifer. In this report, a similar definition of aquifer vulnerability is adopted: The tendency or likelihood for contaminants to reach the top of the FAS after introduction at land surface.

The Wekiva River Coordinating Committee Final Report identified numerous studies by Florida's water management districts and the United States Geological Survey (USGS) that clearly demonstrate contamination attributable to changes in land use. In other words, what occurs on the land directly and indirectly affects the quality of water moving through the subsurface conduits. Many of these conduits flow to surface-water bodies via springs.

The Florida Geological Survey (FGS) applied a modeling technique used in the statewide Florida Aquifer Vulnerability Assessment (FAVA) project to the Wekiva study area in order to delineate relative degrees of vulnerability for the FAS based on available data. This project is known as the Wekiva Aquifer Vulnerability Assessment model or WAVA. The modeling technique used is known as Weights of Evidence (WofE), which is based entirely in a geographic information system (GIS) and is summarized below. For a more thorough explanation of this method refer to FGS Bulletin 67, Florida Aquifer Vulnerability Assessment: Contamination potential of Florida's principal aquifer systems (Arthur et al., 2005, in preparation). The relative vulnerability zones identified in the WAVA model may be applied to facilitate designation of "protection zones" by regulatory agencies. These "protection zones," however, would likely include other physical and chemical (i.e., water quality) factors affecting the hydrologic system, including ground-water flow rates and patterns and proximity to impacted areas.

The software used to execute WofE and the Florida Department of Environmental Protection (FDEP) Albers projection require certain data layers to be listed in meters. However, some data layers are listed in units standard to that particular data set. For reader convenience we list the primary unit followed by the alternative unit in parentheses.

\section{ACKNOWLEDGEMENTS}

The authors are grateful for the work of the Wekiva River Basin Coordinating Committee (WRBCC), which was appointed by the Governor in July, 2003. This committee follows a series of legislation and Governor Executive Orders, all with the ultimate goal of protecting surface- and ground-water resources of the Wekiva River system. The research presented herein was funded by the Florida Springs Initiative through the FDEP, and was facilitated by the support of Vivian Garfein, Director, FDEP Central District, Richard Drew, Bureau Chief, FDEP Water Facilities Regulation and Mike Bascom, FDEP Springs Coordinator. We are thankful for the insightful review comments provided by individuals listed above, including members of the WRBCC, as well as Richard Deadman, Florida Department of Community Affairs. Moreover, we gratefully acknowledge the following individuals for providing technical and/or editorial review of the report: Chris Ferraro, Lou Ley and Alan Stodghill (FDEP), William Pollock and Dr. Eberhard Roeder, Florida Department of Health, and several FDEP/Florida Geological Survey staff, including Carol Armstrong, Dr. Rick Copeland, Tom Greenhalgh, Jackie Lloyd, Frank Rupert, Dr. Tom Scott and Dr. Walt Schmidt. 


\title{
FLORIDA GEOLOGICAL SURVEY
}

\section{WEKIVA AQUIFER VULNERABILITY ASSESSMENT MODEL}

\author{
Weights of Evidence
}

Use of WofE requires the combination of diverse spatial data which are used to describe and analyze interactions and generate predictive models (Raines et al., 2000). When applied in the WAVA project, WofE was used to generate maps of aquifer vulnerability, or response themes. These response themes were generated in the Environmental Systems Research Institute ArcView 3.2 environment. WofE was executed using the Arc Spatial Data Modeler which is available as an internet download (Kemp et al., 2001).

A primary benefit of applying WofE to the WAVA project is that it is data-driven, rather than expertdriven. The data that "train" the model consist of known occurrences of parameters (water quality values) that reflect relative aquifer vulnerability, such as high levels of dissolved oxygen in ground-water wells. These wells were the training points used to calculate weights for laterally continuous input data layers, or evidential themes, which are then combined to yield a response theme.

When reviewing the model results, it is important to note that all aquifers, to some degree, are vulnerable to contamination from land surface. The model results simply identify those areas within the study area that are more vulnerable or less vulnerable based on the evidential themes and training points used in the model. So, the vulnerable areas are assigned values relative to each other within the study area. These "relative" values are not directly transferable or correlated to another study area.

\section{Study Area}

The initial step in the development of the WAVA model was the delineation of a study area extent. The study area, comprised of 30 square meters $\left(\mathrm{m}^{2}\right)\left(322.9 \mathrm{ft}^{2}\right)$ grid cells, was used in the calculation of weights and probabilities throughout the modeling process as described below. The extent of the study area used for input into the WAVA model was based on a combination of the Wekiva study area (as identified in the Wekiva River Basin Coordinating Committee, 2004) and the area contributing ground water to the Wekiva River (Figure 2).

Large water bodies were omitted from the WAVA model because a well would never be drilled in these areas - therefore, they would never contain a training point. Additionally, if lakes were left in the model, the surface area was increased with no chance of increasing the number of training points. This would unnecessarily bias the model. Further, large water bodies typically have no soils or other input data associated with them, thus the model output omits these areas due to lack of data or potential bias in the calculated probabilities. Removal of large water bodies does not change the relative results (i.e., relative vulnerability) of the model; however, it would have the effect of increasing weights calculated during the modeling process. Regardless, the model is more valid and defensible by removing the large water bodies.

Due to the geostatistical framework and evidential layers (spatial hydrogeological data) of WAVA, aquifer systems in discharge areas were sometimes predicted by the output model to be low in vulnerability, even though the discharging surface waters are highly vulnerable to contamination. These discharging surface waters are not part of the aquifer, although they can originate from it. The WAVA project was designed to focus on the ability for a contaminant to travel through soils, overburden, karst features, etc. to enter into the aquifer system. As a result, it is very important that the WAVA model never be applied to assess contamination of surface waters or discharge areas. 


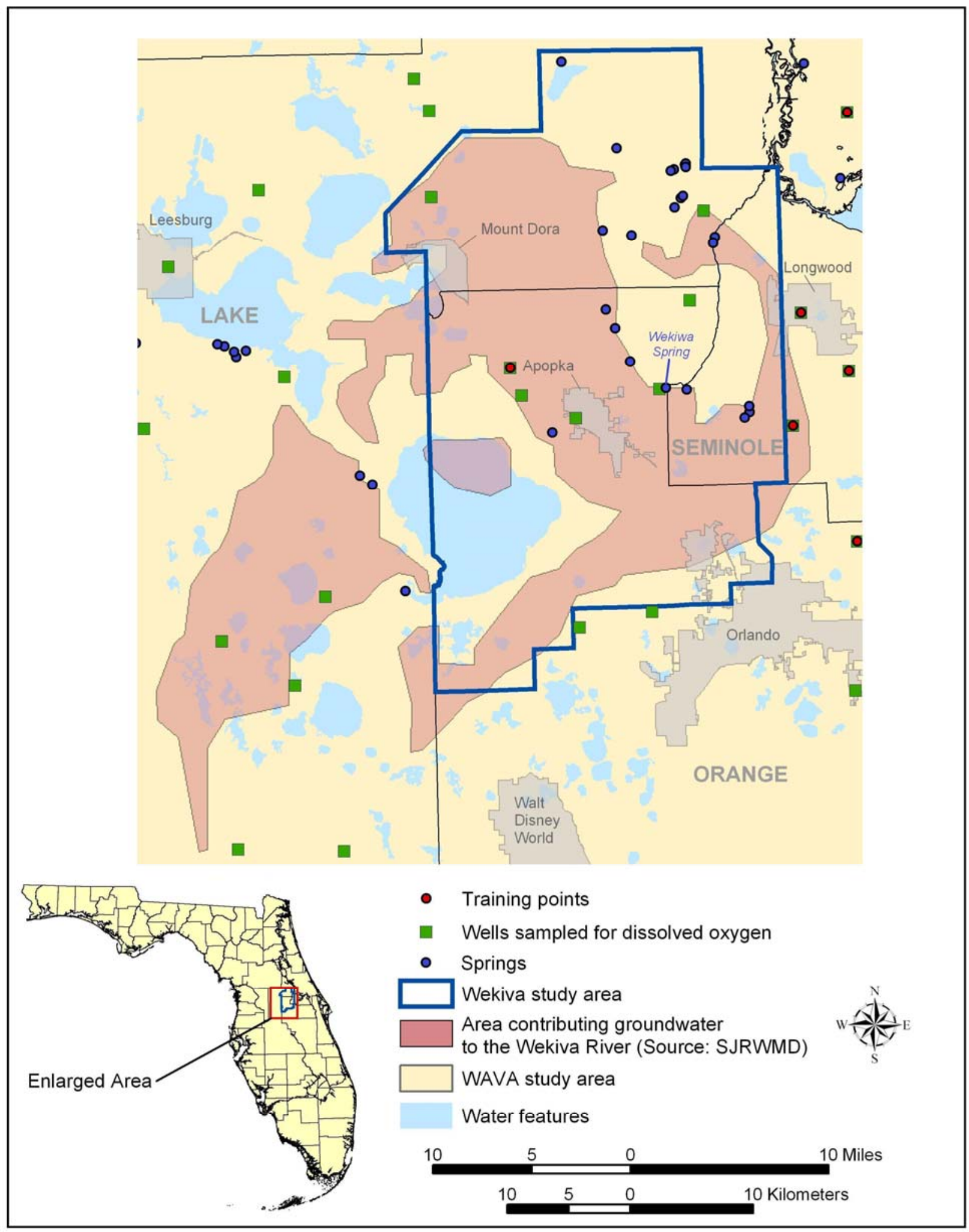

Figure 2. Extent of the WAVA study area and training point set developed based on dissolved oxygen measured in wells. Large water bodies have been omitted from the analysis to avoid biasing the model (see text). Wekiva River Basin Coordinating Committee (WRBCC; March 16, 2004). 


\section{FLORIDA GEOLOGICAL SURVEY}

\section{Training Points}

In WofE, training points are locations of known measured occurrences (i.e., locations where quantitative data have been obtained). In mining applications for example, identified ore reserves are known occurrences (training points). In an aquifer vulnerability assessment, wells with water quality data indicative of high recharge (i.e., dissolved oxygen, nitrates above an identified background threshold, tritium) are potential known occurrences (i.e., areas where a good connection exists between the top of the aquifer and land surface). Training points are used in WofE to calculate the following parameters (see Weights of Evidence Glossary): prior probability, weights for each evidential theme, and posterior probability of the response theme. Training points are converted to represent a unit area (i.e., a $30 \mathrm{~m}^{2}$ grid cell) of the study area within a GIS application.

The water-quality parameter selected for the WAVA training data set was dissolved oxygen. In general, native ground-water concentrations of dissolved oxygen in the FAS are typically low where the aquifer system is not affected by activities at land surface or active recharge. Therefore, where dissolved oxygen occurs at concentrations above background levels in an aquifer system, it can generally be assumed a relatively greater hydrologic connection exists between land-surface activities and ground water. Dissolved oxygen analytical values served as the training point set for the WAVA model.

More than 200 wells completed in the FAS for the WAVA study area were compiled from the FDEP Background Water Quality Monitoring Network, the FDEP STATUS network, and the St. John's River Water Management District monitoring network. Of these wells, 28 were measured for dissolved oxygen. Using statistical methods, described in Arthur et al. (2005, in preparation), two wells were identified as outliers and removed from the dataset leaving 26 wells for further analysis (Figure 2). The $75^{\text {th }}$ percentile value was the statistical break used to identify relatively high dissolved oxygen concentrations in ground water, which is considered herein as a proxy for areas of higher recharge and vulnerability. Median dissolved oxygen concentrations for wells with multiple analyses were calculated. These median values, along with data from wells with one dissolved oxygen analysis were then used to calculate a grand median value. The $75^{\text {th }}$ percentile combined median value for dissolved oxygen concentration was $0.4 \mathrm{mg} / \mathrm{L}$. Six wells existed in the dataset that had a measured median dissolved oxygen value greater than the $0.4 \mathrm{mg} / \mathrm{L}$ threshold. These six wells comprised the training point theme for input into the WAVA model (Figure 2).

The probability that a training point will occupy a defined unit area within the study area, independent of any evidential theme data, is known as prior probability. The prior probability is calculated by dividing a unit area representing the training points by the total study area. In less complex terms, the prior probability is based on prior knowledge of the problem without the benefit of supporting evidence. The prior probability for the WAVA model was calculated at 0.0017. The distribution of all wells sampled for dissolved oxygen, and the wells meeting training point criteria are displayed in Figure 2.

\section{Evidential Themes}

Several evidential themes were considered for use in the WAVA model due to their potential influence on ground-water quality. They are:

- Soil permeability

- Buffered effective karst features (based on closed topographic depressions)

- Thickness of Intermediate Aquifer System (IAS)

- Hydraulic head difference between Surficial Aquifer System (SAS) and FAS

- Vertical leakage rate to and from the FAS 
Vertical leakage rate to and from the FAS ultimately was not used because it was based on model simulations with a grid-cell size of 1,000 meters and there was large variability in the calculated leakage rate between adjacent grid cells. Weights were calculated for each of the other four evidential themes and generalized as discussed below.

\section{Generalization of Evidential Themes}

Evidential themes were generalized in an effort to assess which areas of the evidence shared a greater association with locations of training points. During calculation of weights for each evidential theme used in the WAVA project, a contrast value was calculated for each class of the theme by combining the positive and negative weights (positive weight - negative weight). Contrast is a measure of a theme's significance in predicting the location of training points and helps to determine the threshold or thresholds that maximize the spatial association between the evidential theme map pattern and the training point theme pattern (Bonham-Carter, 1994). Arthur et al., (2005, in preparation) provide a more comprehensive explanation of theme generalization.

Confidence of the evidential theme equals the contrast divided by the standard deviation (a student T-test) for a given evidential theme and provides a useful measure of significance of the contrast due to the uncertainties of the weights and areas of possible missing data (Raines, 1999). A confidence value of 1.282 corresponds to a $90 \%$ level of significance (see Table 1), which was the value selected as the minimum acceptable confidence level for the WAVA project evidential themes. Confidence values approximately correspond to the statistical levels of significance listed in Table 1.

Table 1. Test values calculated in WofE and their respective studentized $T$ values expressed as level of significance in percentages.

\begin{tabular}{|ll|}
\hline $\begin{array}{l}\text { Studentized T Value } \\
\text { (confidence expressed as level of significance) }\end{array}$ & Test Value \\
\hline $99.5 \%$ & 2.576 \\
\hline $99 \%$ & 2.326 \\
\hline $97.5 \%$ & 1.960 \\
\hline $95 \%$ & 1.645 \\
\hline $90 \%$ & 1.282 \\
\hline $80 \%$ & 0.842 \\
\hline $75 \%$ & 0.674 \\
\hline $70 \%$ & 0.542 \\
\hline $60 \%$ & 0.253 \\
\hline
\end{tabular}

Contrast values were used to determine where to sub-divide evidential themes into generalized categories. The most common method of categorizing an ordered evidential theme was to select the maximum contrast as a threshold value to create a binary generalized evidential theme. In some WofE models, categorization of more than two classes may be justified (Arthur et al., 2005, in preparation). For evidential themes used for the WAVA project, a binary break was typically defined by the WofE analysis thereby creating two spatial categories: one with stronger association with the training point theme and one with weaker association with the training point theme. 


\title{
FLORIDA GEOLOGICAL SURVEY
}

\author{
Soil Permeability
}

Soil permeability values were obtained from the soils statewide grid layer developed for FAVA (Arthur et al., 2005, in preparation), which was compiled from the United States Department of Agriculture Natural Resources Conservation Service - Soil Service Geographic (SSURGO) data set. This database was mapped at a scale of 1:24,000 and contains the most detailed soil permeability data. However, different permeability values can exist along some county boundaries due to the different mapping techniques used by different soil scientists. The development of this layer included the calculation of average soil permeability values for each soil horizon layer. Then, based on soil horizon thicknesses, weighted-average permeability values were calculated for the entire soil column. This allowed the generation of a data coverage of soils containing a single permeability value per soil polygon. This data coverage is displayed in Figure 3. Missing-data areas on the figure represent urban land, pits and water features.

Soil permeability is a measure of the rate at which water travels through the vadose (unsaturated) zone. Areas with high soil permeability values are normally associated with higher aquifer vulnerability. Weights were calculated for soil permeability using the cumulative descending method (refer to Weights of Evidence Glossary) of the WofE model technique. The highest contrast of any class was calculated at $13.1 \mathrm{in} / \mathrm{hr}\left(9.2 \times 10^{-3} \mathrm{~cm} / \mathrm{sec}\right)$ as displayed in Figure 4. Based on the calculated weights, the most appropriate break in the soil permeability evidential theme was at $13.1 \mathrm{in} / \mathrm{hr}\left(9.2 \times 10^{-3} \mathrm{~cm} / \mathrm{sec}\right)$, creating a binary generalized theme for input into the WAVA model. This contrast break indicated that values exceeding $13.1 \mathrm{in} / \mathrm{hr}\left(9.2 \times 10^{-3} \mathrm{~cm} / \mathrm{sec}\right)$ were strongly correlated with aquifer vulnerability as defined by the training point data, whereas values less than $13.1 \mathrm{in} / \mathrm{hr}\left(9.2 \times 10^{-3} \mathrm{~cm} / \mathrm{sec}\right)$ were less significant. The generalized theme is displayed in Figure 5.

\section{Buffered Effective Karst Features}

To represent karst features (i.e., sinkholes) affecting vulnerability in the WAVA model study area, an effective karst GIS grid was generated based on a combination of closed topographic depressions identified in USGS 7.5-minute quadrangle maps and thickness of overburden on FAS (Figure 6). Closed topographic depressions (considered an estimation of karst feature distribution) are represented on USGS 7.5-minute maps as enclosed hachured contour lines. The effective karst feature evidential theme was developed by evaluating which of these closed topographic depressions were more likely to be hydrologically connected to the underlying FAS. This was accomplished by filtering out depressions underlain by more than 100 feet (30.5 m) of FAS overburden thickness. The $100-\mathrm{ft}(30.5 \mathrm{~m})$ threshold of overburden thickness has been used to identify karst-prone areas by Cichon et al. (2004) and Wright (1974). Though the location of training points was not used to select this filter threshold, the lack of their occurrence in areas underlain by more than 100 feet $(30.5 \mathrm{~m})$ of FAS overburden thickness lends support to the use of this filter.

Areas nearer to an effective karst feature are normally associated with higher aquifer vulnerability due to the increased chance of overland flow and the infiltration into the depression. Therefore, buffer zones of 3,600-m (11,811 ft) divided into 30-m (98.4 ft) intervals were generated around each karst feature, and weights were calculated for the effective karst feature evidential theme using the cumulative ascending method. The highest contrast of any class was calculated at a distance of $60 \mathrm{~m}(196.9 \mathrm{ft}) \mathrm{from} \mathrm{a}$ depression creating a binary generalized theme for input into the WAVA model. In other words, the analysis indicated that this threshold of proximity to karst features maximized the spatial association between the map pattern and the training point pattern. The generalized theme is displayed in Figure 7. 


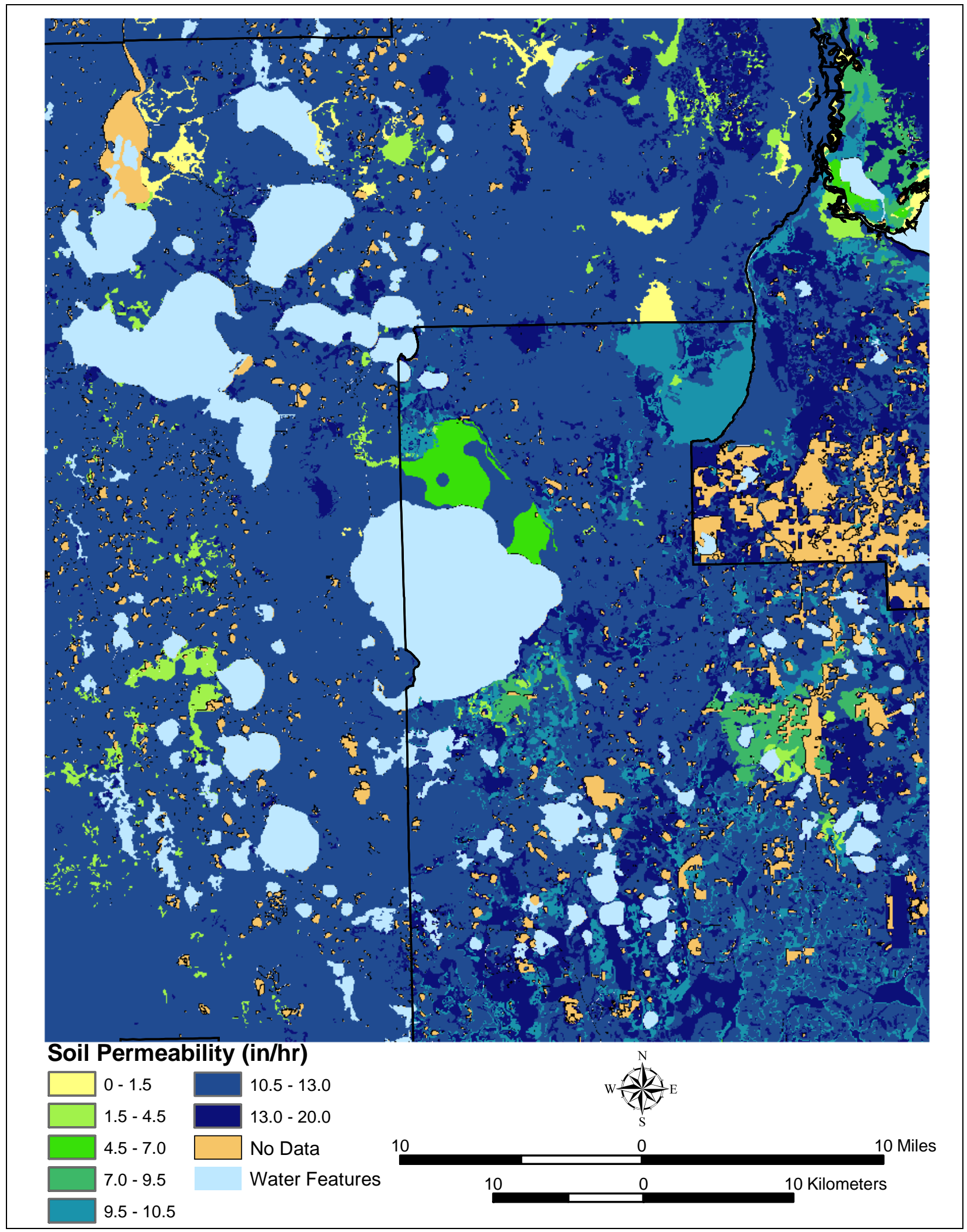

Figure 3. Soil permeability map of the WAVA study area (Florida Geographic Data Library, 2003). Note differences across county lines due to different mapping techniques. Missing-data areas represent urban land, pits and water features. 


\section{FLORIDA GEOLOGICAL SURVEY}

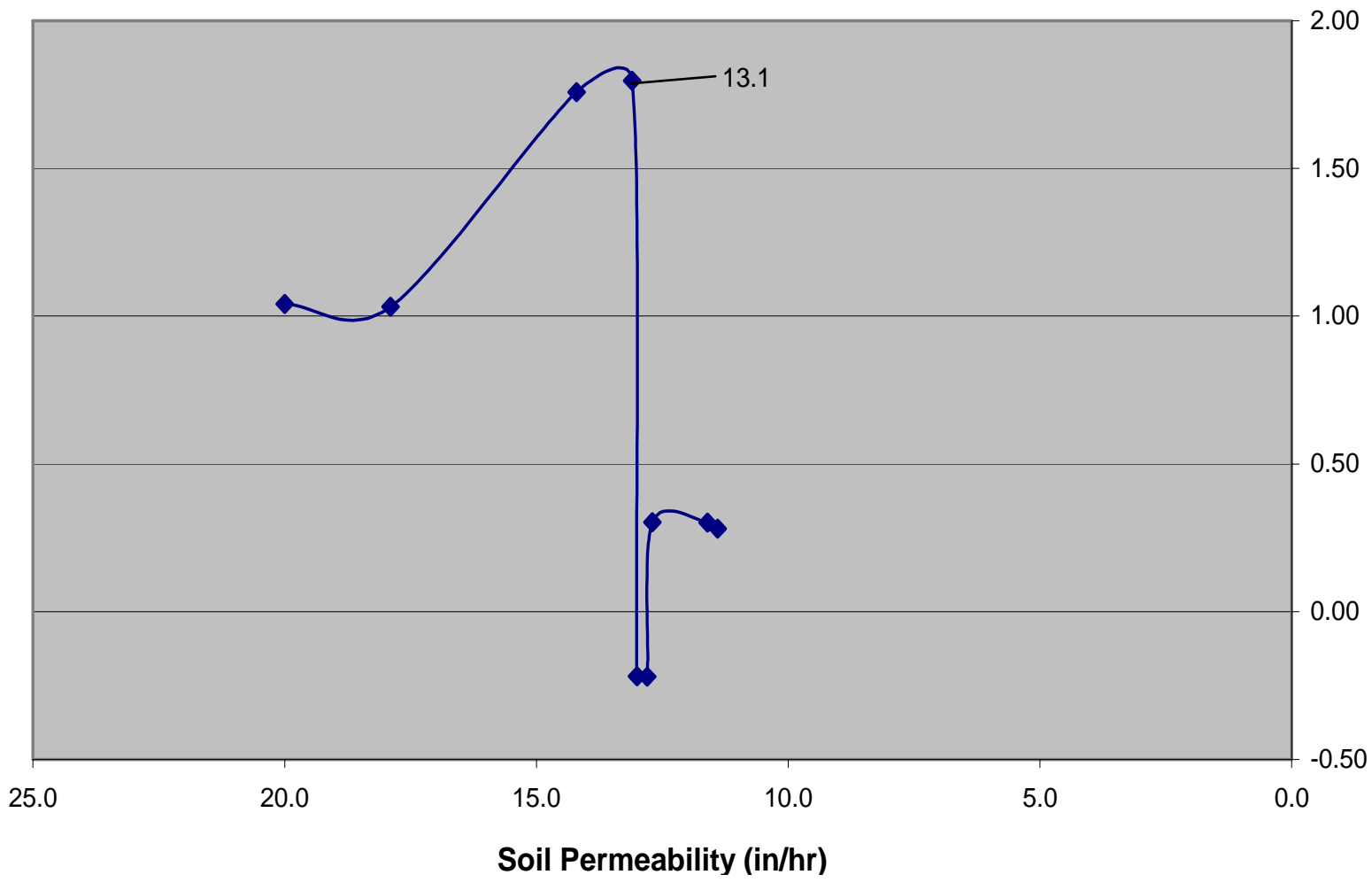

Figure 4. Soil permeability values (in/hr) plotted against contrast values calculated using WofE. The highest contrast value was calculated at $13.1 \mathrm{in} / \mathrm{hr}\left(9.2 \times 10^{-3} \mathrm{~cm} / \mathrm{sec}\right)$.

Thickness of the Intermediate Aquifer System

For the purposes of the WAVA project, "Intermediate Aquifer System," or IAS, refers to the statewide hydrostratigraphic unit that provides variable confinement to the FAS. The initial step in the identification of the IAS was to create a database of well core and cuttings data. The well database was then used to create a hydrostratigraphic surface for the top of the IAS and the top of the FAS (which coincides with the base of the IAS). Following creation of these surface models, it was necessary to resolve the IAS with land-surface elevation in localized areas where the IAS surface interpolation extended above land surface. After the hydrostratigraphic surfaces were developed and refined, calculation of a thickness map was completed by subtraction of the IAS surface from the FAS surface. The final output yielded a continuous thickness map of the IAS; however the map could not take into account areas of zero IAS thickness due to the grid calculation. As a result, based on data from more than 24 wells within and immediately adjacent to the study area, an approximate extent of the IAS was delineated. These areas, which are located within the northeastern and southwestern part of the WAVA study area are depicted on Figure 8 as "IAS thin to absent" and are juxtaposed against the calculated grid results. 


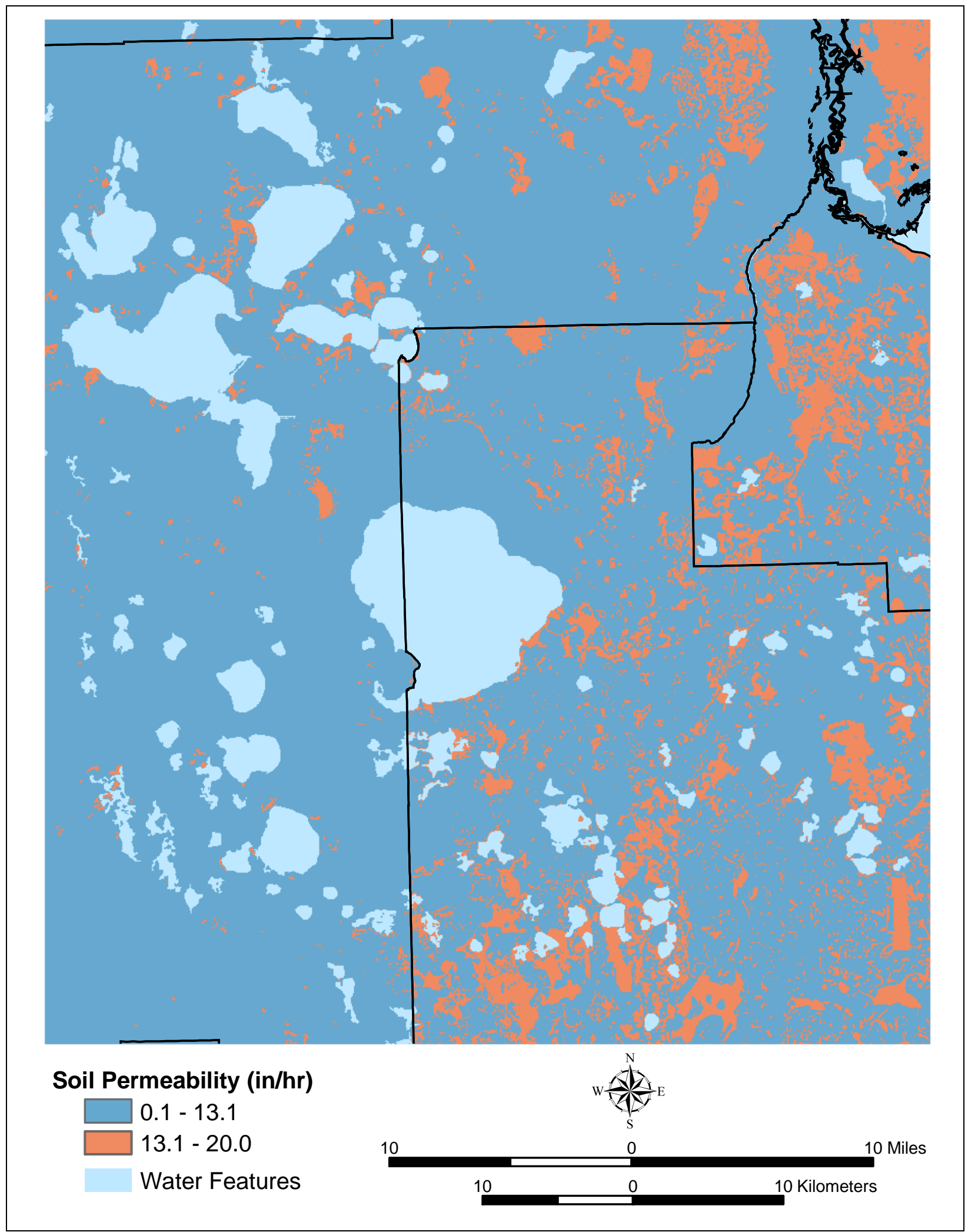

Figure 5. Map showing binary generalization of the soil permeability evidential theme, based on a contrast value of $13.1 \mathrm{in} / \mathrm{hr}\left(9.2 \times 10^{-3} \mathrm{~cm} / \mathrm{sec}\right)$. 


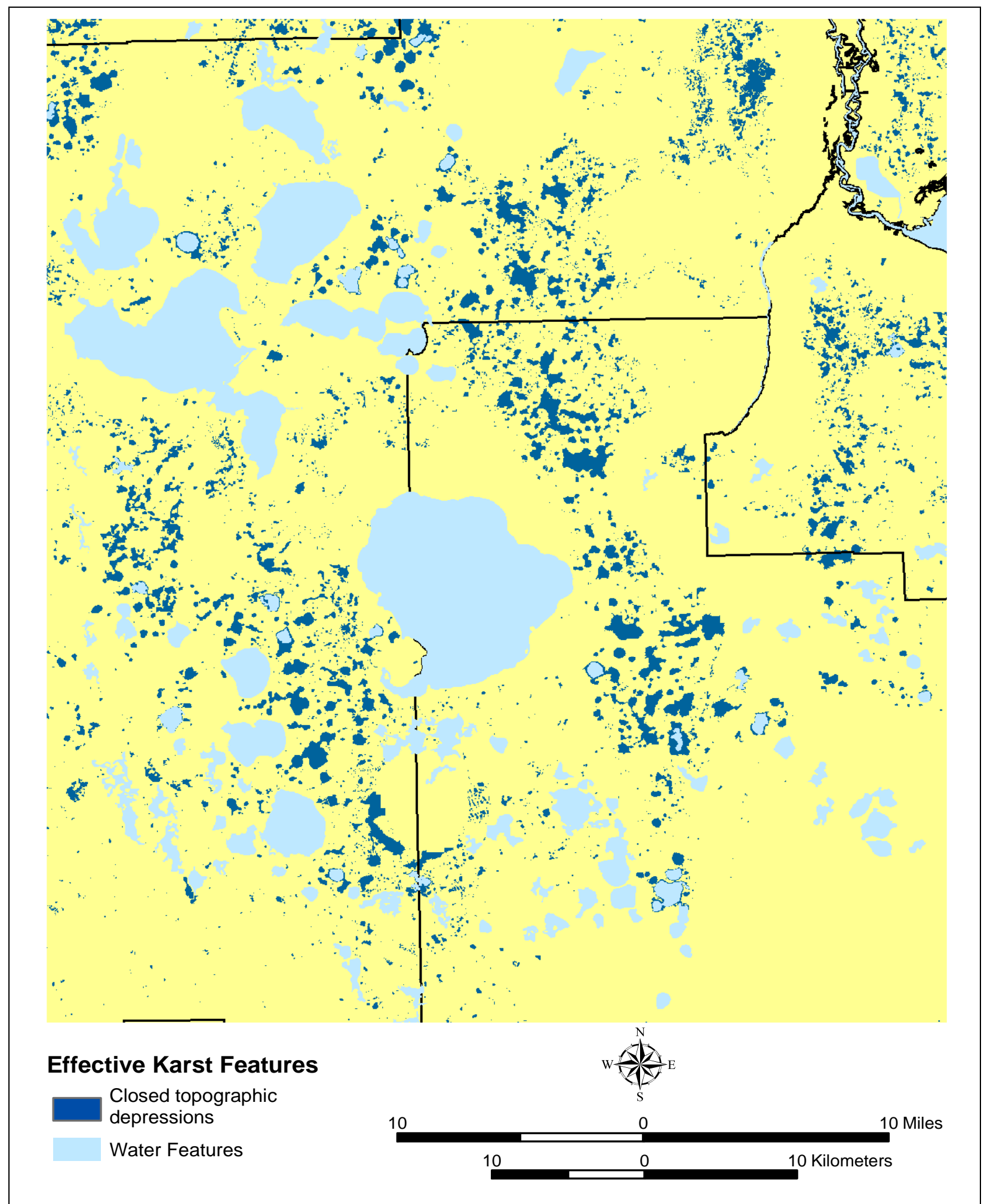

Figure 6. Closed topographic depressions underlain by less than 100 feet $(30.5 \mathrm{~m})$ of FAS overburden. 


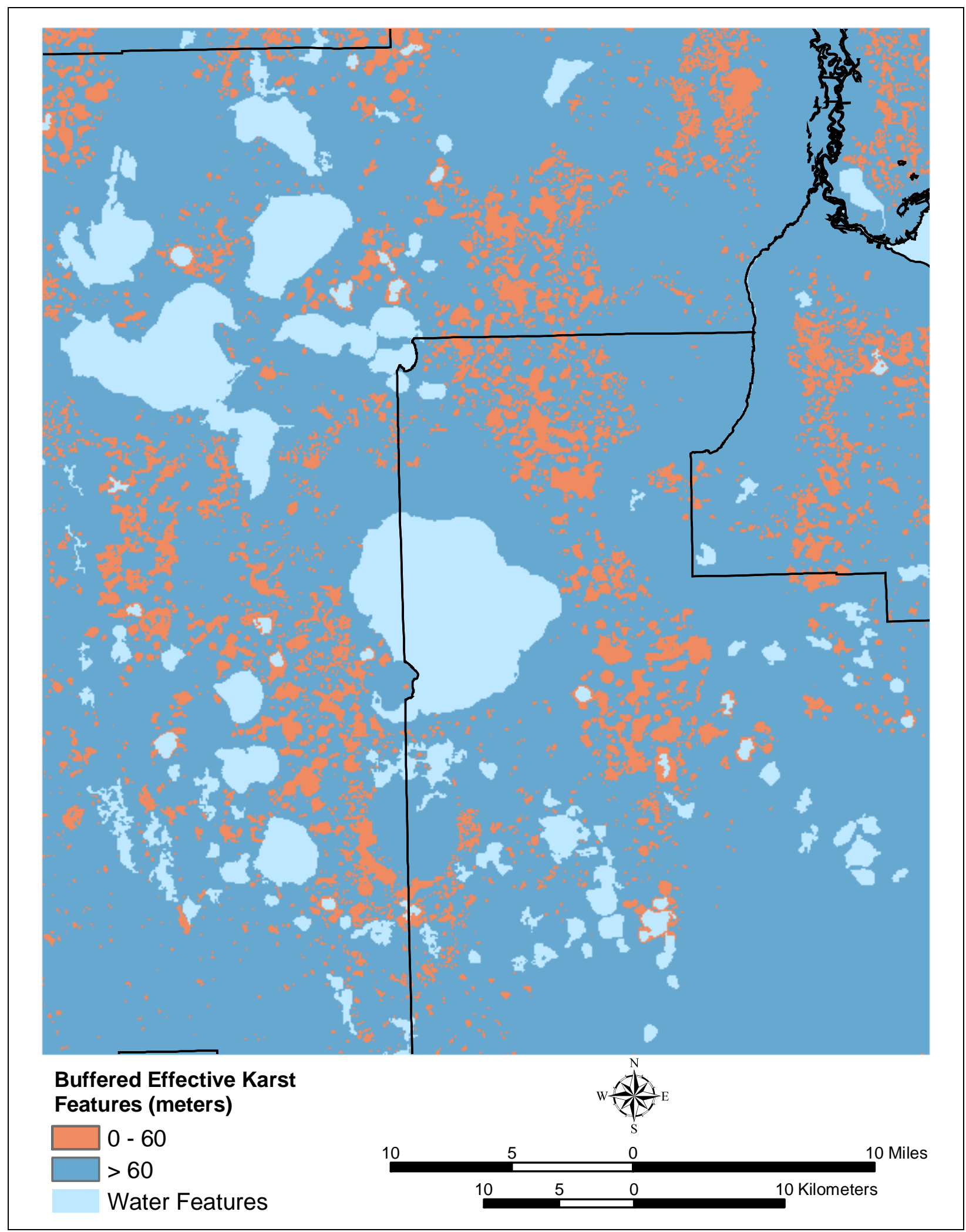

Figure 7. Map showing binary generalization of the buffered effective karst features evidential theme based on a contrast buffer distance of $60 \mathrm{~m}(196.9 \mathrm{ft})$. 


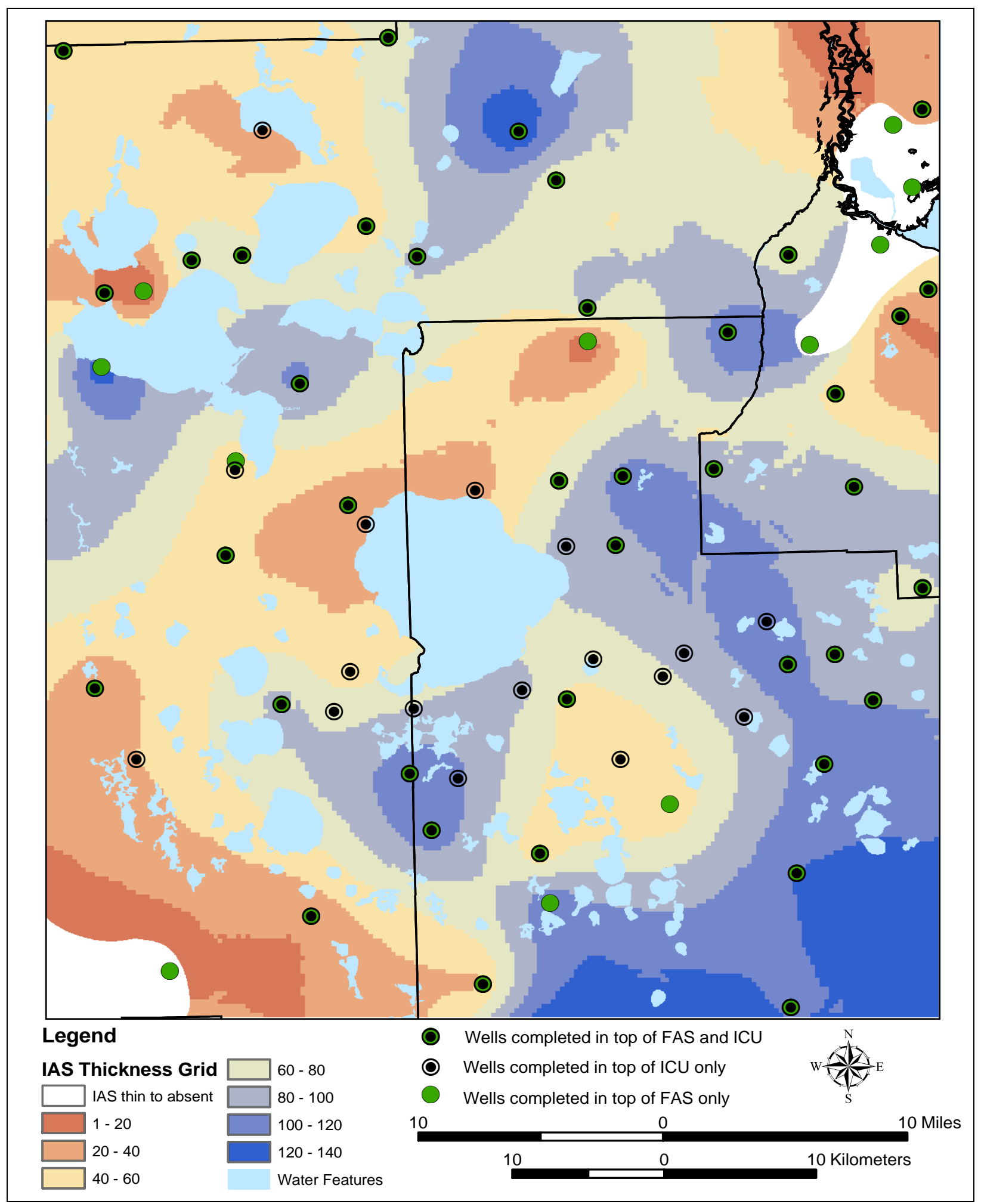

Figure 8. Thickness grid of IAS (in feet) and the distribution of wells used. Data from FGS lithologic database combined with geophysical well logs (Davis et al., 2001) were utilized to develop this coverage. See text for explanation of "IAS thin to absent" areas. 
Areas underlain by thinner IAS sediments are normally associated with higher aquifer vulnerability. Weights were therefore calculated for the IAS evidential theme using the cumulative ascending method. The highest contrast of any class was calculated at a thickness of 48 feet $(14.6 \mathrm{~m})$ creating a binary generalized theme for input into the WAVA model (Figure 9). In other words, the analysis indicated that this threshold of IAS thickness maximized the spatial association between the map pattern and the training point pattern.

The best available data indicated that the area including Wekiwa Spring is underlain by 50 feet (15.2 m) or more of IAS thickness. This data included well core and cuttings data and geophysical (gamma) well logs from FGS lithologic database and FGS Special Publication No. 50 (Davis et al., 2001). As a result, for this analysis, the spring is located outside the area which is strongly correlated with aquifer vulnerability as defined by the training point data (i.e., greater than 48 feet or $14.6 \mathrm{~m}$ thick). In fact, the exposed rocks within the spring pool are the Coosawhatchie Formation of the Hawthorn Group which is part of the IAS (Harley Means, personal communication, 2004).

\section{Hydraulic Head Difference between SAS and FAS}

Hydraulic head difference was calculated by subtracting the FAS 1993-1994 potentiometric surface (Sepulveda, 2002) from the water-table surface (Arthur et al., 2005, in preparation). Although more recent potentiometric surfaces for the FAS have been published, the data control in Sepulveda's (2002) map was more dense and the potentiometric surface was more highly resolved. Areas with a positive hydraulic head difference value indicated that the FAS is receiving recharge, whereas areas with a negative value indicated the FAS is discharging to the overlying aquifer system (Figure 10).

Areas of greater hydraulic head difference between the SAS (water table) and FAS indicate greater potential for downward recharge to the FAS, which is normally associated with higher aquifer vulnerability. Weights were therefore calculated for the hydraulic head difference evidential theme using the cumulative descending method. The highest contrast of any class was calculated at a hydraulic head difference value of $17 \mathrm{ft}(5.2 \mathrm{~m})$ creating a binary generalized theme for input into the WAVA model. In other words, the analysis indicated that this threshold of hydraulic head difference maximized the spatial association between the map pattern and the training point pattern. Figure 11 displays the binary generalization used for the hydraulic head difference evidential theme.

\section{Response Theme}

The WAVA response theme is an output map, calculated using WofE, showing the probability (posterior probability) that a unit area is vulnerable to contamination from land surface based on the evidence provided. A response theme is portrayed as relative vulnerability and is classified based on the inflections in a chart in which cumulative study area is plotted against posterior probability. The chart may allow for the selection of several classes of posterior probability. The more vulnerable areas correspond with higher posterior probabilities, while the less vulnerable areas are associated with lower posterior probabilities. In essence, a higher posterior probability indicates that an area is more likely to contain a training point, or more likely to be contaminated, and therefore more vulnerable to contamination from land surface.

As described in the Introduction, the WAVA model was based on the modeling technique used in the FAVA project. The FAVA project identified relative vulnerability of Florida's principal aquifer systems and consolidated the results into three classes (more vulnerable, vulnerable and less vulnerable). The FAVA response theme clipped to the Wekiva study area (Figure 12) shows that the majority of the 


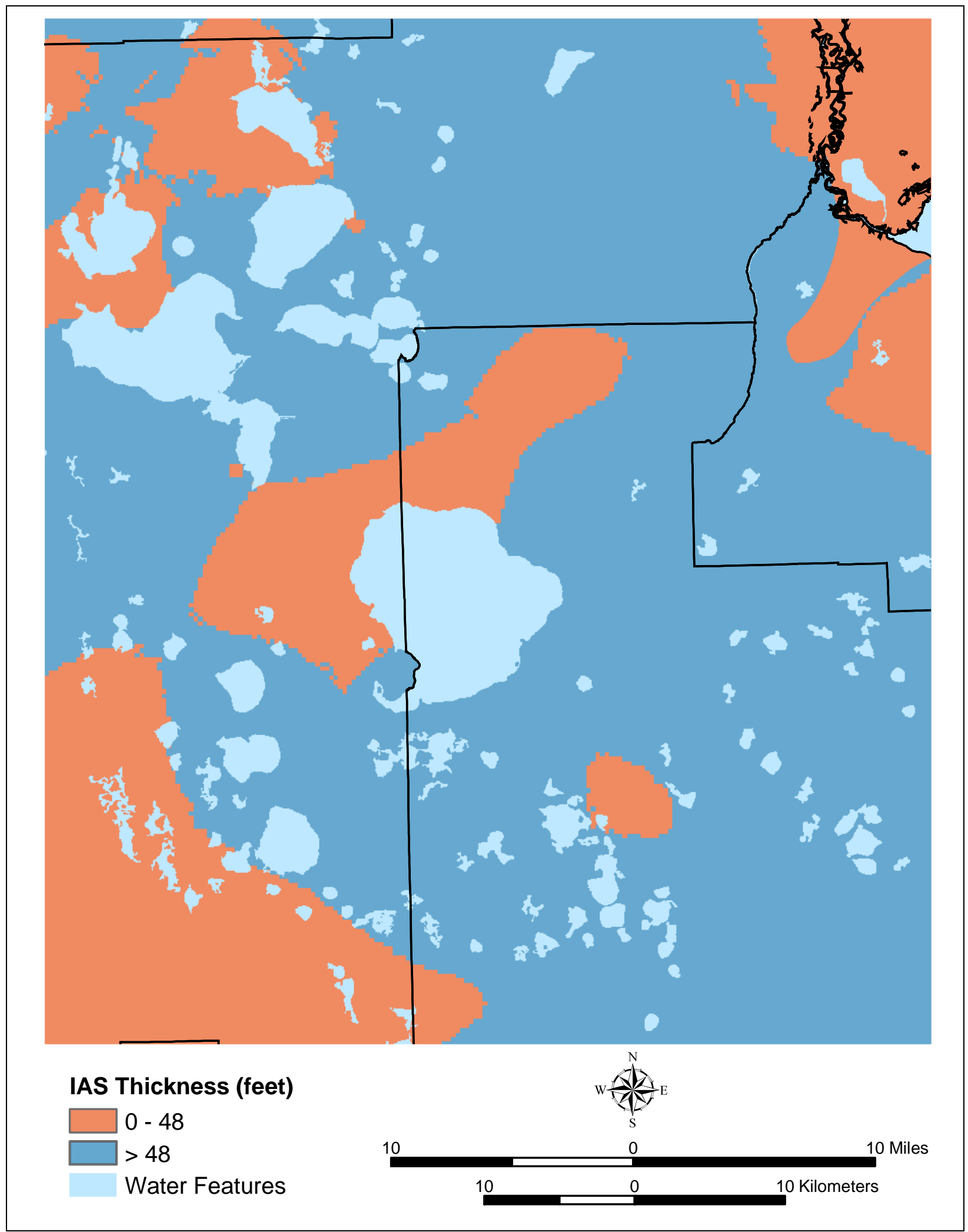

Figure 9. Map showing binary generalization of the IAS thickness evidential theme based on a contrast value of $48 \mathrm{ft}(14.6 \mathrm{~m})$. 


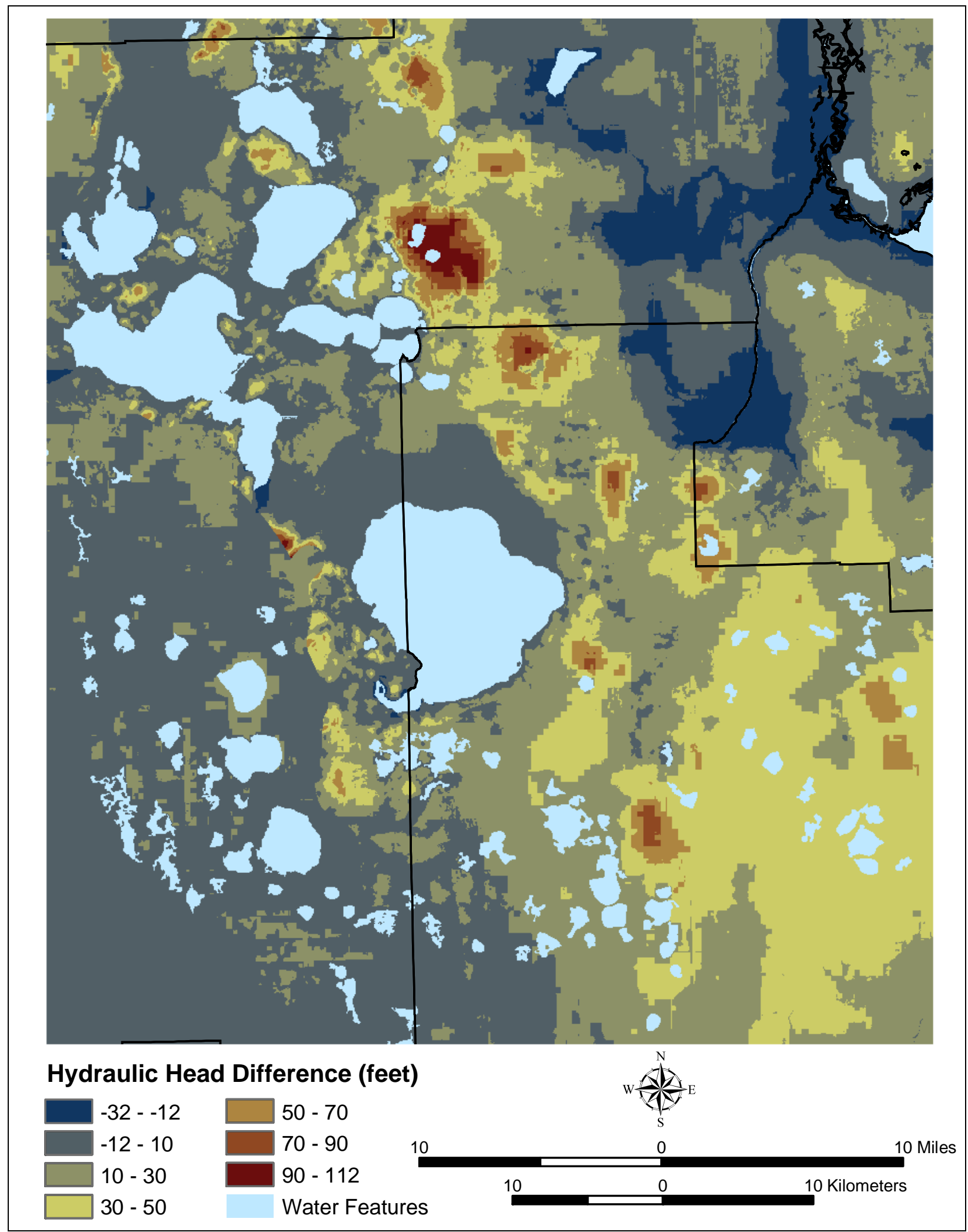

Figure 10. Hydraulic head difference between the SAS (Arthur et al., 2005, in preparation) and the FAS potentiometric surface (Sepulveda, 2002). 


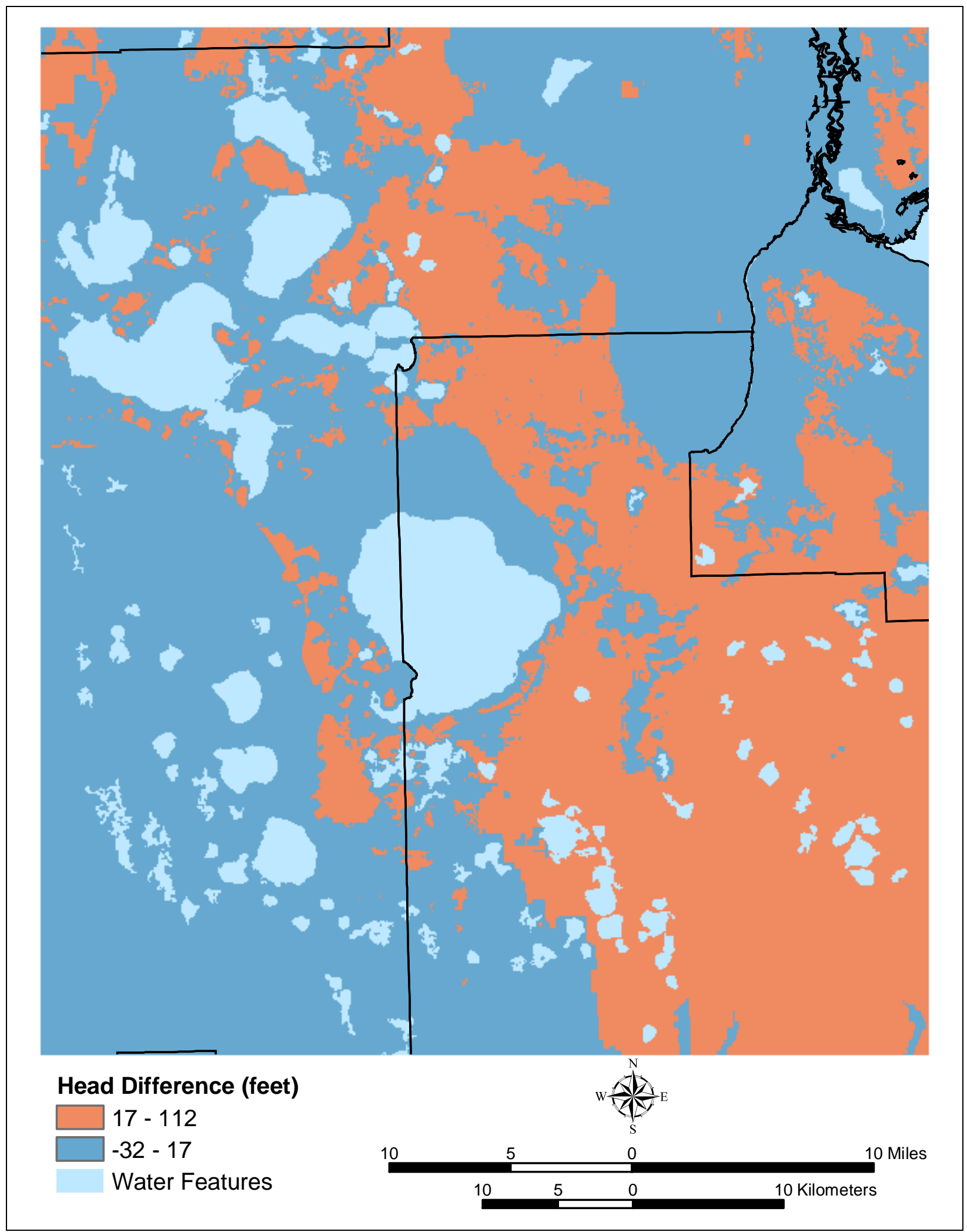

Figure 11. Map showing binary generalization of the hydraulic head difference evidential theme based on a contrast value of $17 \mathrm{ft}(5.2 \mathrm{~m})$. 


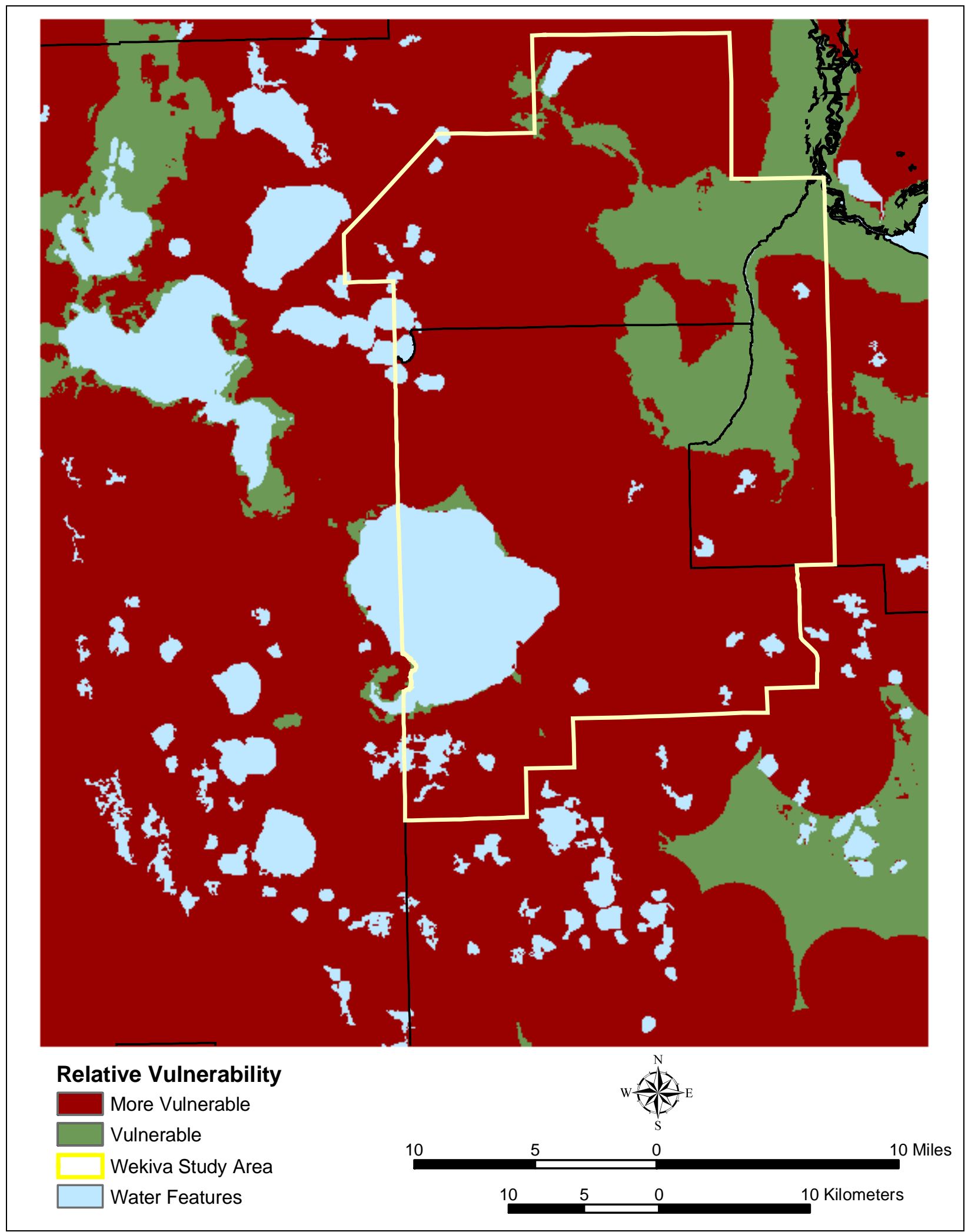

Figure 12. Relative vulnerability of the FAS FAVA model (Arthur et al., 2005, in preparation) showing zones of vulnerability based on the extent of the Floridan Aquifer System. 


\section{FLORIDA GEOLOGICAL SURVEY}

Wekiva study area is located in the "more vulnerable" zone. A smaller part of the study area is located in the "vulnerable" zone and none of the study area is located in the "less vulnerable" zone. By applying the FAVA modeling technique to the Wekiva study area (i.e., applying the WAVA model) it was possible to delineate refined zones of relative vulnerability by considering only the range of hydrogeological conditions in the study area as opposed to statewide hydrogeological conditions. Although the Wekiva study area should be considered "vulnerable" to "more vulnerable" in the context of statewide FAS vulnerability, the WAVA model refines these two degrees of vulnerability into three classes.

Using the four evidential themes discussed above, a response theme was generated showing the posterior probability that a unit area contained a training point based on the evidential themes provided. A conceptual model showing the association between the training points and the evidential themes is shown in Figure 13. The posterior probabilities of the response theme ranged from 0.0007261 to 0.1042028 across the model domain. Plotting posterior probability against cumulative area as a percentage (Figure 14) allowed the delineation of class breaks for display of protection zones in the final response theme (Figure 15). The breaks for these protection zones were selected where a notable stepwise increase in posterior probability relative to the cumulative study area occurred. The first break, which delineated the less vulnerable zone from the vulnerable zone, occurred at a posterior probability value of 0.0000990 . The less vulnerable zone represents approximately $25.7 \%$ of the study area. The second break delineating the vulnerable zone from the more vulnerable zone occurred at the next significant stepwise increase in posterior probability at a value of 0.0017000 , which corresponded with the prior probability. This vulnerable zone represents approximately $55.8 \%$ of the study area. The remainder of the study area includes the more vulnerable zone and represents approximately $18.4 \%$ of the study area. This more vulnerable zone contains the greatest probability of containing a training point, and is therefore considered the most vulnerable to contamination from land surface.

For the purposes of this project, three vulnerability classes were delineated; however, based on the methodology used to select these classes, a third probability break could be delineated, representing less than $3 \%$ of the study area. This area would represent the most vulnerable part of model study area and would be located principally in the "more vulnerable" area defined in the FAVA study.

The response theme indicated that the areas of highest vulnerability (high probabilities) tended to be associated with IAS sediments that are thin to absent, dense karst-feature distribution, high positive hydraulic head difference, and high soil permeability. Conversely, areas of lowest vulnerability (low probabilities) tended to be determined by thick IAS sediments, sparse karst-feature distribution, hydraulic head difference less than 17 feet (5.2 m) and low soil permeability values.

In addition to the large surface-water bodies present in the study area, a multitude of other surface-water features occur (Figure 16). Many of these features represent areas of discharge. It is important to note that these discharging surface waters are not part of the aquifer, although they originate from it. The WAVA project was designed to predict the relative ability for a contaminant introduced at land surface to travel through soils, overburden, karst features, etc. to enter into the FAS. As a result, it is essential that the WAVA model never be applied to assess contamination of surface waters or discharge areas.

As described earlier, an assumption is made when using WofE that there is conditional independence between the layers used as predictors. Conditional independence is violated when the presence of one evidential theme influences the probability of another evidential theme. The validity of posterior probability values depends upon the degree of conditional independence calculated for the model. 


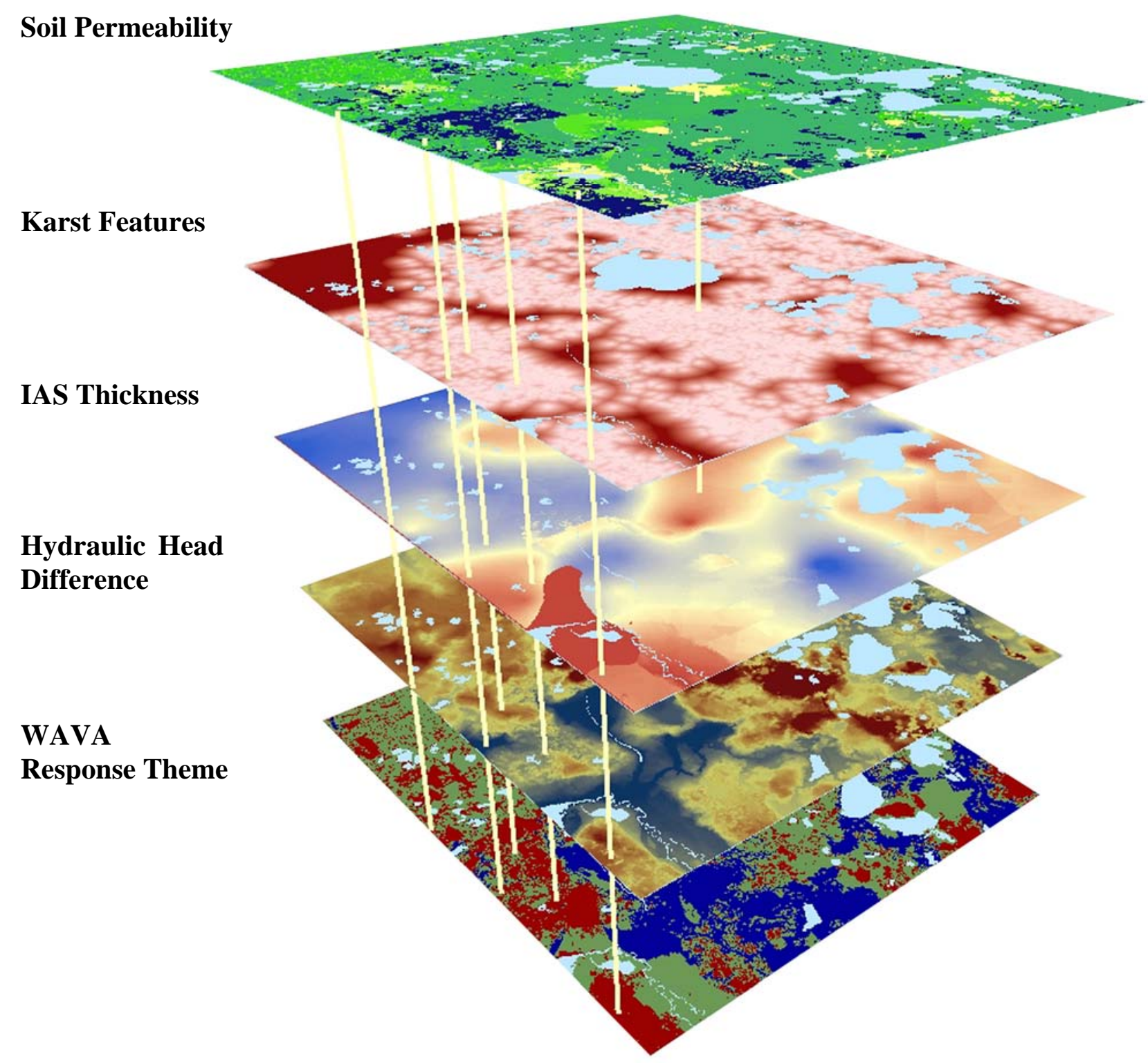

Figure 13. WofE conceptual model of the FAS. The top four layers are evidential themes and the bottom layer is the response theme divided into zones of relative vulnerability. Yellow lines represent training points (wells) projected throughout the layers. 


\section{FLORIDA GEOLOGICAL SURVEY}

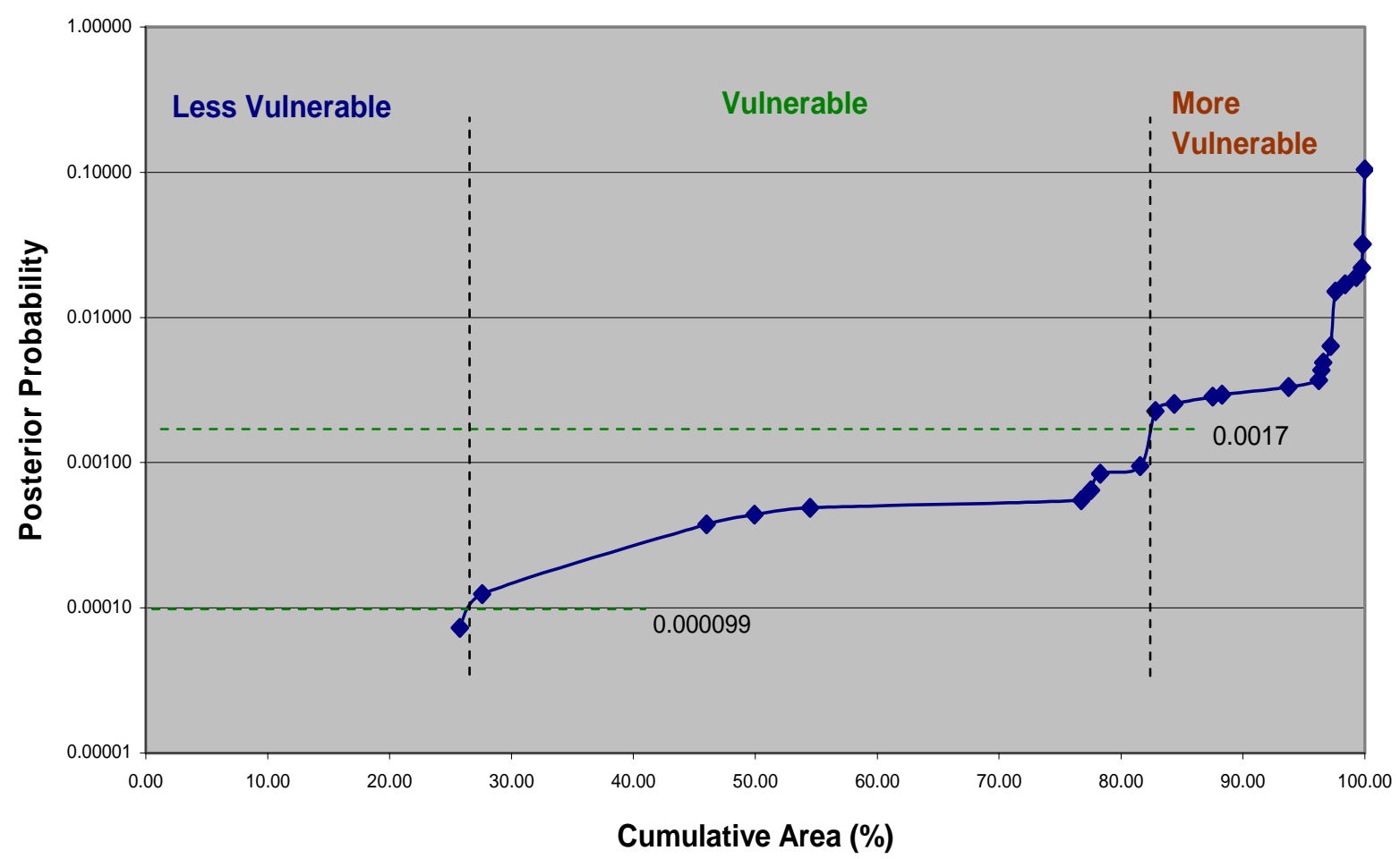

Figure 14. Posterior probability class breaks (green dashed lines) representing the boundaries between zones of relative vulnerability. A fourth optional break occurs at a posterior probability of 0.017, which would represent less than $3 \%$ of the study area.

Evidential themes are considered independent of each other if the conditional independence value is around 1.00. For the WAVA project, appropriate conditional independence values fell within the range of $1.00 \pm 0.15$ (Gary Raines, personal communication, 2003). Conditional independence was calculated at 1.15 indicating minimal dependence between evidential themes.

Weights calculated for the evidential themes used in the WAVA model are included in Table 2. This table displays the evidential themes used, weights calculated for those evidential themes, as well as the contrast and confidence of the evidential theme. A positive weight indicates areas where training points were likely to occur, while a negative weight indicates areas where training points were not likely to occur. The contrast column is a combination of the highest and lowest weights (positive weight negative weight) and is a measure of how well the generalized evidential themes predict training points. A

Table 2. WofE final output table listing weights calculated for each evidential theme and their associated contrast and confidence values of the evidential themes.

\begin{tabular}{|lllll|}
\hline Evidential Theme & W1 & W2 & Contrast & Confidence \\
\hline Hydraulic Head Difference & 0.7412 & -1.2857 & 2.0269 & 1.8494 \\
\hline Buffered Effective Karst & 1.3546 & -0.5550 & 1.9096 & 2.3343 \\
\hline Soil Permeability & 1.2564 & -0.5396 & 1.7960 & 2.1955 \\
\hline IAS Thickness & 0.8739 & -0.7726 & 1.6465 & 1.8994 \\
\hline
\end{tabular}




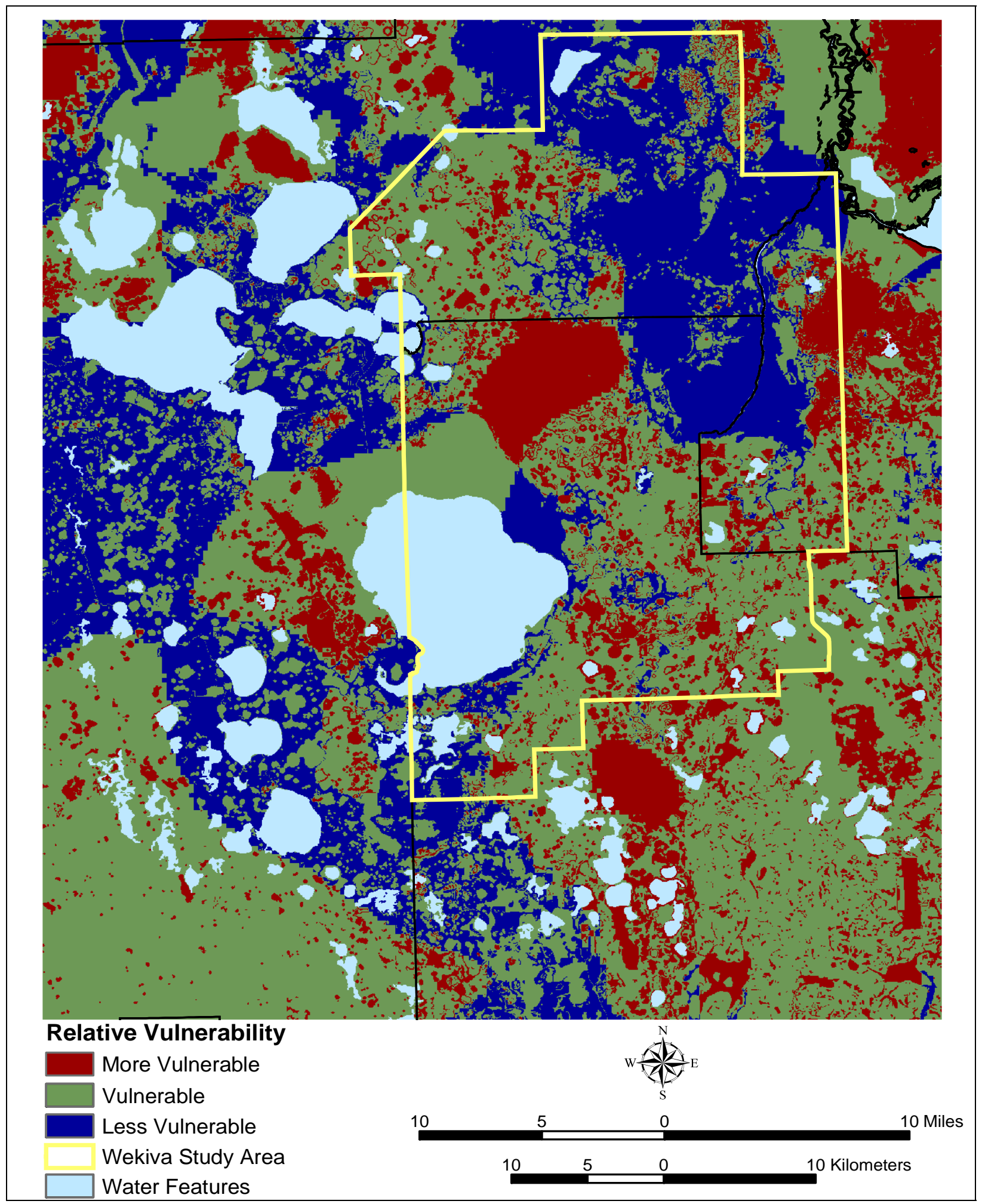

Figure 15. Relative vulnerability predicted by the WAVA model showing more vulnerable, vulnerable and less vulnerable areas of the FAS. 


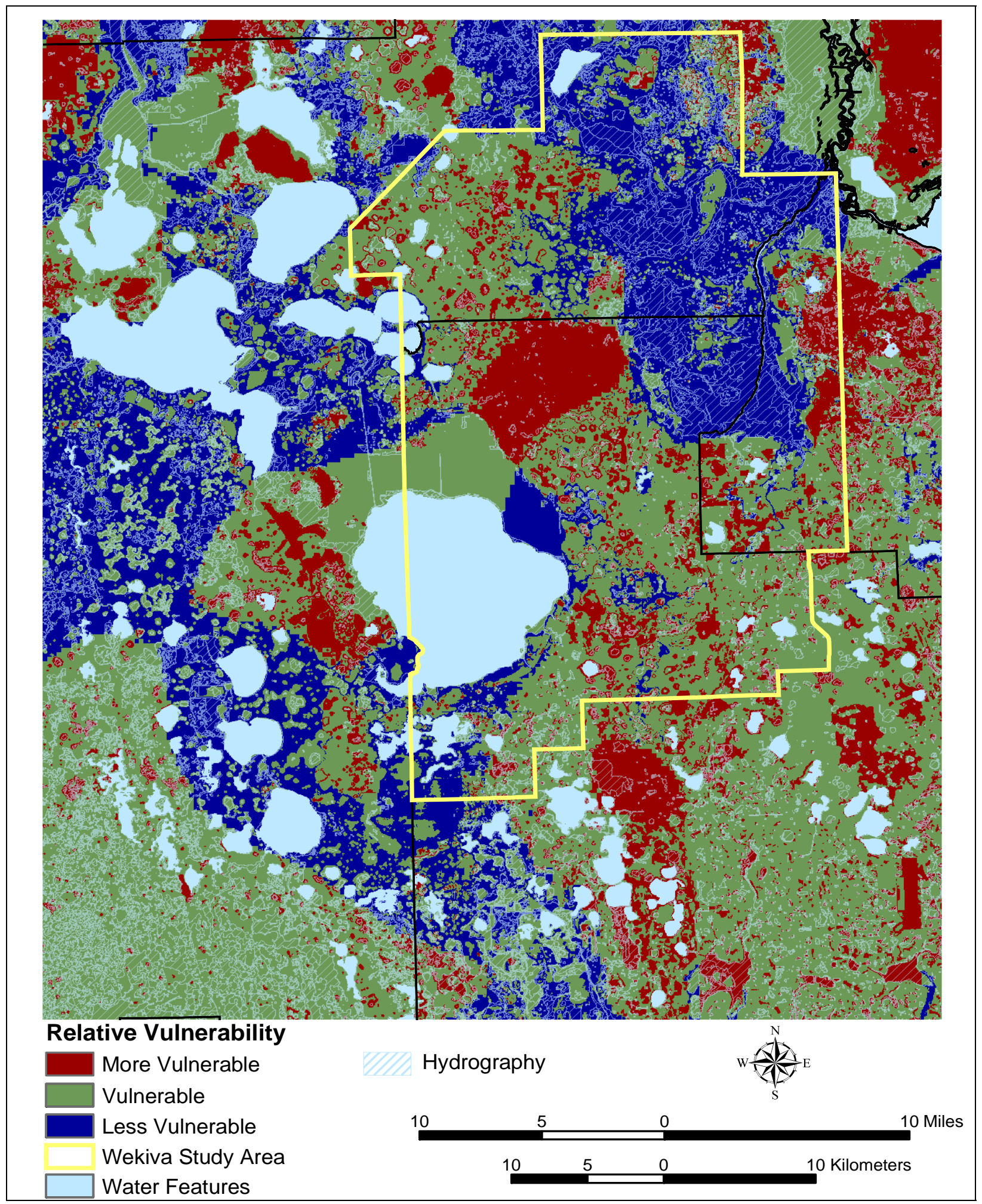

Figure 16. Relative vulnerability predicted by the WAVA model showing more vulnerable, vulnerable and less vulnerable areas of the FAS. Hydrography represents seasonal and permanent wetlands, ponds and small lakes. 
positive contrast that is significant, based on its confidence, suggests that a generalized evidential theme is a useful predictor. The confidence of the evidential theme is the contrast divided by its standard deviation and provides a useful measure of significance of the contrast because of the uncertainties of the weights and areas of missing data (Raines, 1999).

The hydraulic head difference evidential theme had a stronger association with the training points (i.e., highest contrast) than the other evidential themes and was therefore the primary determinant in predicting areas of vulnerability in this model. Three of the evidential themes (buffered effective karst, confining unit thickness and soil permeability) indicated where training points were more likely to occur because the positive weights (W1) were stronger (had a greater absolute value) than the negative weights (W2). Confidence values, for each evidential theme, exceeded the target value of 1.282, which corresponds to a level of significance of approximately 90\% (Table 1). In fact, all confidence values for the evidential themes exceeded the 95\% level of significance (1.645). For the dissolved oxygen response theme all of the training points occurred within areas of higher vulnerability, thus supporting the results of the model output.

The soil permeability evidential theme contains large areas of missing data particularly along the Orange and Seminole county border. To compensate for this in the statewide FAVA model, a nearest neighbor GIS function was employed, which was used to apply spatial statistics (Euclidean distance functions) to predict soil permeability data values for these areas. Although this worked well on a statewide scale, use of this process on a smaller area skewed the vulnerability where there were large areas of missing data. In the WAVA model for example, use of this nearest neighbor function caused these areas along the Orange and Seminole county border to be included in the more vulnerable zone of the response theme. However, if the nearest neighbor function was not used, the calculated response theme included these same areas in the vulnerable zone (Figure 17). Based on the uncertainty due to missing data, the nearest neighbor function was not used in the WAVA model. The response theme values in these areas were therefore based solely on IAS thickness, buffered effective karst features, and hydraulic head difference. As a result, the relative vulnerability in these areas of missing data has a higher degree of uncertainty when compared to other areas of the model, and as new data becomes available, the vulnerability of these areas can be re-assessed.

\section{Confidence Map}

There are two types of confidence used on the WofE model. Confidence of the evidential theme, as reported in Table 2 and discussed above in Generalization of Evidential Themes, equals the contrast divided by the standard deviation (a student T-test) for a given evidential theme (Raines, 1999). The second type of confidence can be calculated for each response theme by dividing the theme's posterior probability by its total uncertainty (standard deviation). A confidence map can be generated based on these calculations. The confidence map for the WAVA response theme is displayed in Figure 18.

Areas with a high posterior probability tend to have higher confidence values and therefore have a higher level of certainty with respect to predicting aquifer vulnerability. A small population of training points along with missing data raises the total uncertainty for the response theme which in turn lowers the confidence. A confidence (of posterior probability) map containing all evidential themes (Figure 18) can therefore contain a lower level of significance than those calculated for each separate evidential theme.

\section{Validation and Sensitivity Analysis}

For other aquifer vulnerability assessments completed by the FGS (Arthur et al., 2005, in preparation; Baker et al., 2005) models were validated by creating a training point theme based on another parameter that reflected vulnerability yet was independent of the original training point set. As mentioned above, the 


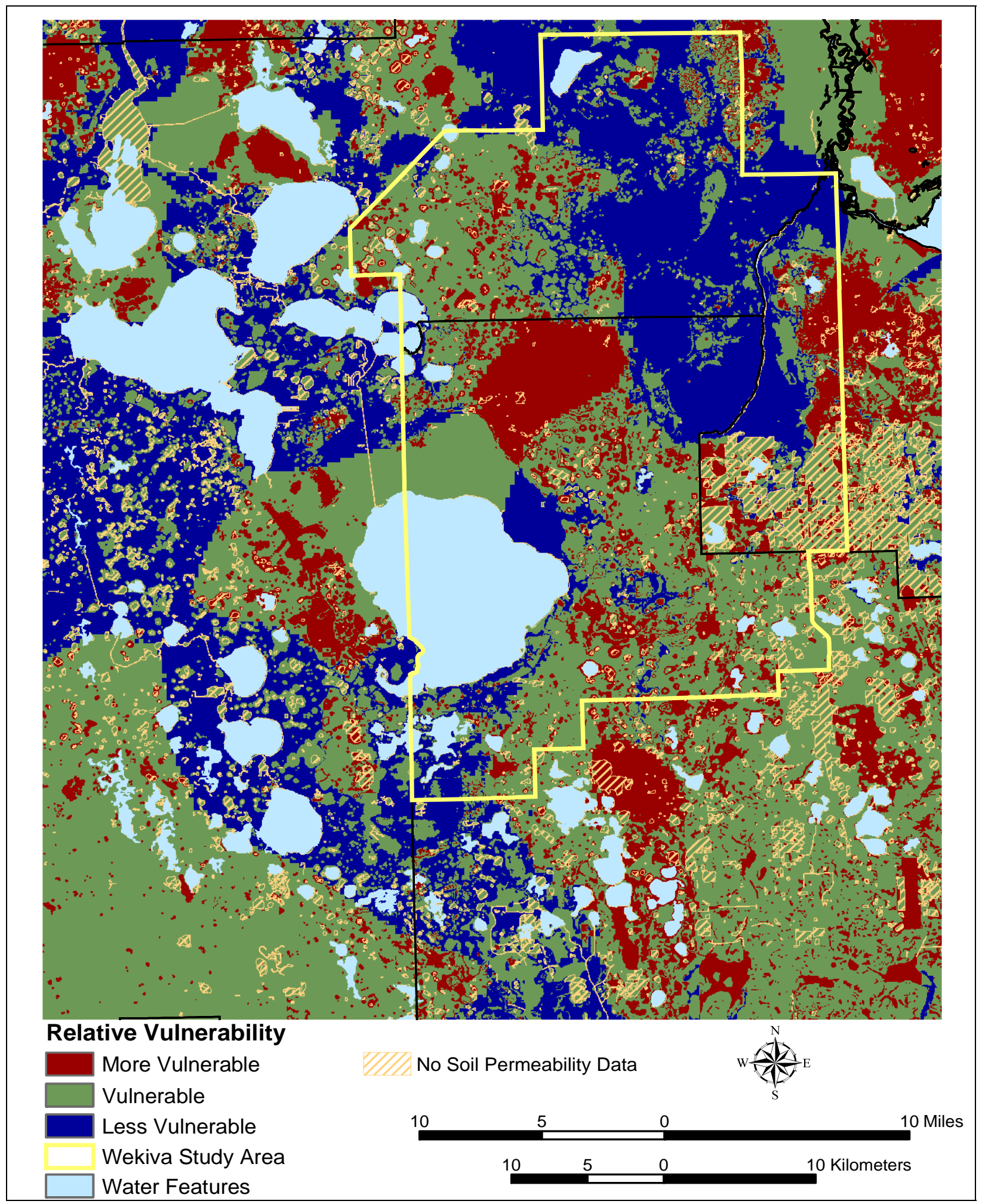

Figure 17. Relative vulnerability predicted by the WAVA model showing areas where no soil permeability data exists. The relative vulnerability predicted in these areas could change (i.e., higher or lower) as new data becomes available. 


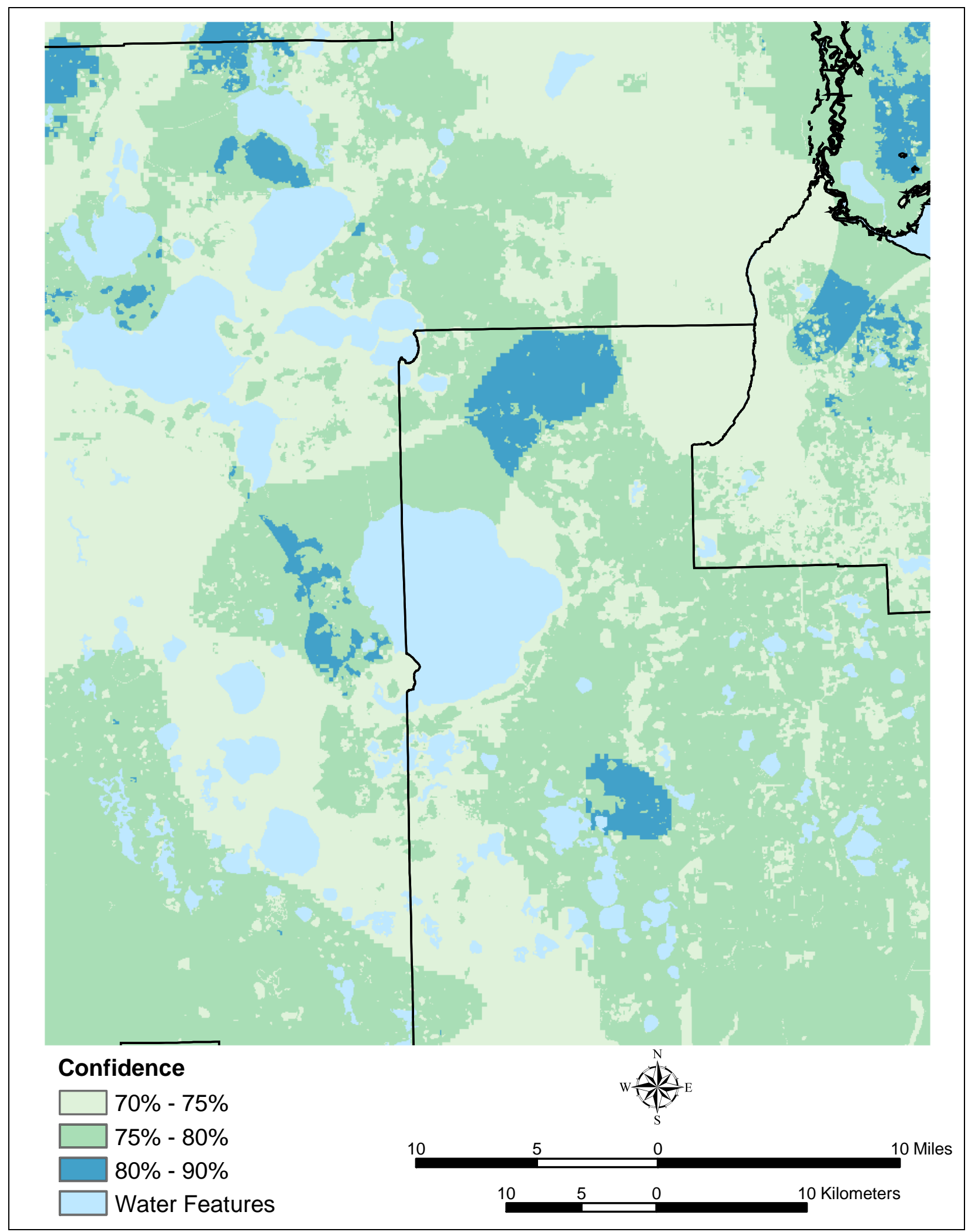

Figure 18. Distribution of confidence values calculated for WAVA response theme. 


\section{FLORIDA GEOLOGICAL SURVEY}

WAVA response theme, based on calculated weights, was a better predictor of where training points were more likely to occur because the positive weights (W1) were stronger than the negative weights (W2). In contrast, results from using a dissolved nitrogen training point set as validation for the WAVA model, indicated where training points were less likely to occur because the negative weights (W2) were stronger than the positive weights (W1). This produced a different kind of model, and, as a result, was not comparable to the original WAVA response theme. The following methods, however, did prove effective in completing reliable validation and sensitivity analyses: comparison of dissolved oxygen and posterior probability, and comparison of the WAVA model with a model based on a subset of training-point data.

\section{Dissolved Oxygen Data vs. Posterior Probability}

Posterior probability values were compared with the dissolved oxygen dataset from which the training point theme was extracted. Dissolved oxygen median concentration values were plotted versus posterior probability values (Figure 19). As expected a positive trend was observed between posterior probability and dissolved oxygen values and a calculated Pearson's correlation coefficient (r) of 0.689 indicates more than a 99\% degree of statistical significance.

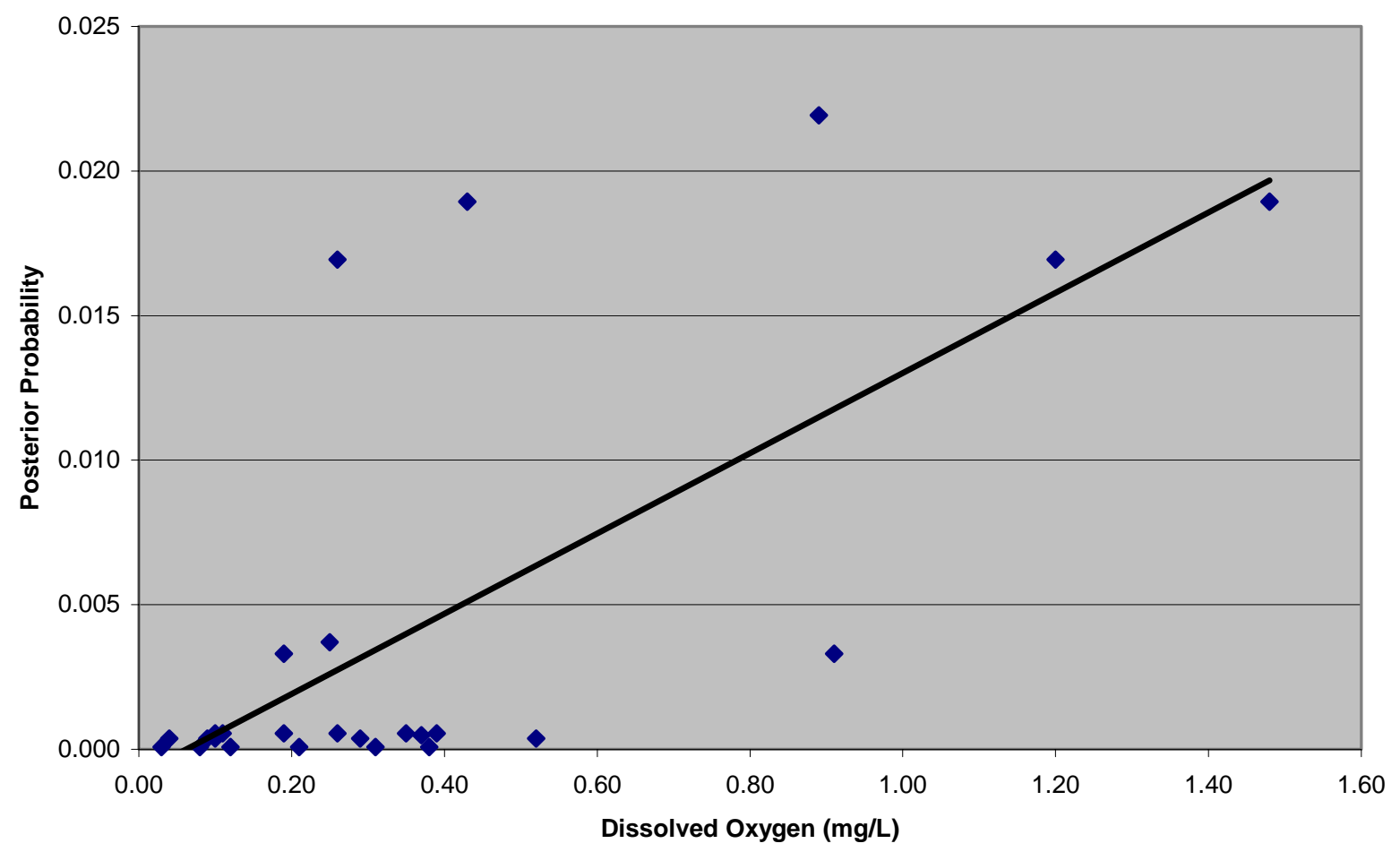

Figure 19. Posterior probability vs. dissolved oxygen median concentration values

\section{Random 75\% Subset of Training Points}

If the WAVA evidential themes and training points were robust (i.e., not sensitive to subtle changes in the training data set), one would expect the response theme patterns for the full training data set and a subset to be similar. For this sensitivity test, a training point theme consisting of a random subset of $75 \%$ of the original training points was generated and the model was re-executed. Response themes generated for the random subset of points were broken into the three relative vulnerability zones using the methodology described in the Response Theme section. The subset response theme was used to evaluate the degree of correlation between the WAVA response theme and the response theme developed using the $75 \%$ subset 
of training points. This random subset yielded a prior probability of 0.0014 . Weights were then recalculated for each evidential theme, class breaks were selected, and a response theme was generated (Figure 20). The pattern of posterior probabilities was nearly identical to the original total dissolved oxygen response theme.

In order to compare quantitatively the WAVA response theme to the random $75 \%$ subset response theme, the kappa coefficient (Cohen, 1960) was applied. This parameter is used to measure the amount of spatial agreement between response themes while taking into account agreement that could have occurred by chance.

Cross-tabulation matrices were used to calculate the kappa coefficient (see also Weights of Evidence Glossary). Values along the diagonal in the initial matrix (Table 3; see bold numbers) reflect the amount of agreement between response themes by area (in square meters). The remaining values in the table reflect where the response themes were mismatched. The matrix allows further matrix calculations of observed and expected proportions (i.e., agreement). The kappa coefficient between the two response themes equals 0.979 and less than $2 \%$ of the study area is mismatched.

Kappa coefficient results can range between -1 (perfect disagreement) and 1 (perfect agreement). A value of zero indicates that the agreement was no better than that expected due to chance (Bonham-Carter 1994). Kappa coefficients calculated in the WAVA project were all positive values. Positive kappa coefficients can be interpreted using Table 4. Based on results of the kappa coefficient, the two response themes are in "almost perfect agreement." This finding, as well as the correlation between dissolved oxygen and posterior probability provides strong validation for the WAVA model.

Table 3. Cross-tabulation matrix of the area in square meters per class of the WAVA response theme and $75 \%$ subset response theme. Values along the diagonal reflect the amount of agreement.

\begin{tabular}{|c|c|c|c|c|c|}
\hline \multirow{2}{*}{\multicolumn{2}{|c|}{ Class }} & \multicolumn{4}{|c|}{ 75\% Subset Response Theme } \\
\hline & & More Vulnerable & Vulnerable & Less Vulnerable & Total \\
\hline \multirow{4}{*}{ 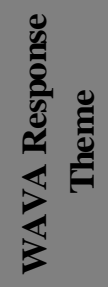 } & More Vulnerable & $608,123,700$ & $43,521,300$ & 0 & $651,645,000$ \\
\hline & Vulnerable & 0 & $1,974,464,100$ & 0 & $1,974,464,100$ \\
\hline & Less Vulnerable & 0 & 0 & $910,533,600$ & $910,533,600$ \\
\hline & Total & $608,123,700$ & $2,017,985,400$ & $910,533,600$ & $3,536,642,700$ \\
\hline
\end{tabular}

Table 4. Kappa coefficient values and their associated interpretation (Landis and Koch, 1977).

\begin{tabular}{|ll|}
\hline Interpretation of kappa values for positive agreement \\
\hline Kappa & Interpretation \\
\hline$<0$ & No agreement \\
\hline $0.0-0.19$ & Poor agreement \\
\hline $0.20-0.39$ & Fair agreement \\
\hline $0.40-0.59$ & Moderate agreement \\
\hline $0.60-0.79$ & Substantial agreement \\
\hline $0.80-1.00$ & Almost perfect agreement \\
\hline
\end{tabular}




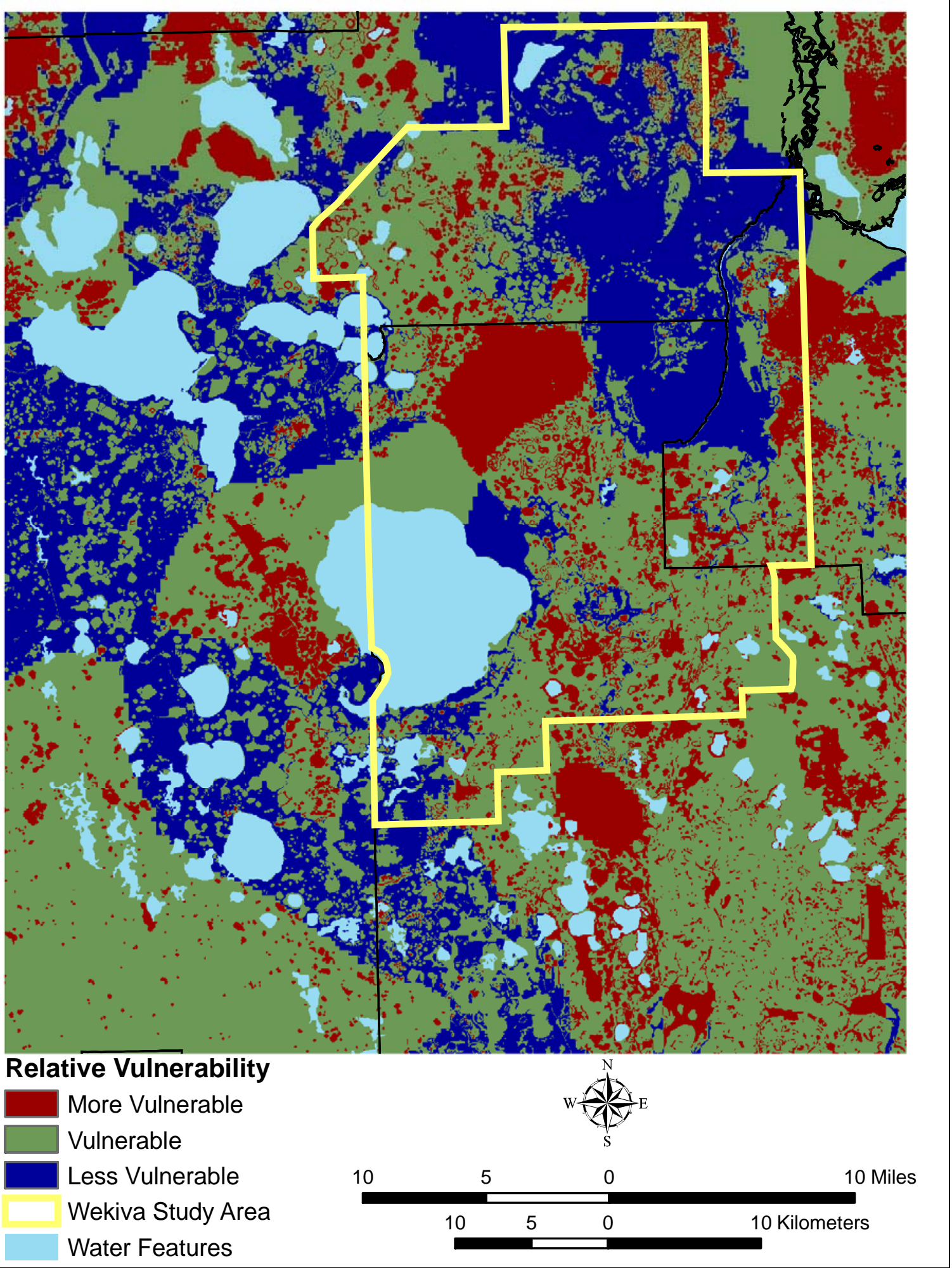

Figure 20. Relative vulnerability of the FAS predicted by the WAVA model using a random $75 \%$ subset of the original dissolved oxygen training point theme. 


\section{REPORT OF INVESTIGATION NO. 104}

\section{Discussion and Summary}

Results of the statewide FAVA model (Arthur et al., 2005, in preparation) predict that the Wekiva study area lies within the "vulnerable" to "more vulnerable" zones of relative vulnerability (Figure 12). The WAVA map, however, provides more detail due to the smaller study area and refined datasets. Using FAVA as a point of statewide reference, the entire Wekiva study area should be considered at a minimum "vulnerable." Even the "less vulnerable" zones predicted by the WAVA map are "vulnerable" with respect to the findings of the FAVA study. In agreement with hydrogeological principles, the "more vulnerable” zones predicted by the WAVA model (Figure 15) correspond to areas of relatively thin confinement, high karst-feature density, higher soil permeability and larger differences in hydraulic head between the water table and the FAS potentiometric surface.

Within the Wekiva study area, the largest and most laterally continuous zone predicted as "more vulnerable” occurs approximately three miles ( 4.8 kilometers [km]) north-northeast of Lake Apopka; whereas much of the "less vulnerable" areas are predicted to occur along the northeastern part of the Wekiva study area as well as east and south of Lake Apopka. Several "more vulnerable" areas located outside of the Wekiva study area yet within the WAVA study area correspond to population centers, such as Orlando. Future land-use planning in these areas will hopefully consider the results of the WAVA model as measures are developed to protect local ground-water resources.

In summary, all aquifer systems in Florida are vulnerable to contamination. This is not only attributable to Florida's hydrogeologic setting but also to human modifications of the natural system. The WAVA project results provide a probability map that identifies zones of relative vulnerability in the study area based on the evidential themes and training points used as input for the model. Because the model input consists only of natural systems characteristics that affect aquifer vulnerability, the WAVA output map is consequently an approximation of intrinsic aquifer vulnerability (i.e., it does not account for sources of contamination or behavior of contaminants). The methodology used to produce the WAVA map is a data-driven process, which minimizes the potential for scientific bias.

The maps are as accurate as the most detailed input layer, and as inaccurate as the least detailed layer. It is the responsibility of the end-users of these maps to determine specific and appropriate applications (see also Disclaimer). It is recommended that the WAVA vulnerability map should be applied at scales smaller than 1:200,000 (i.e., 1:500,000). Implementing this scale recommendation prohibits application of the vulnerability map to assess individual land parcels. Although much of the input data and the output vulnerability map are accurate to a raster resolution of $30 \mathrm{~m}^{2}\left(322.9 \mathrm{ft}^{2}\right)$, use of the map at this scale is not suggested. Application of the vulnerability map on the order of greater than .75 square miles $\left(1.94 \mathrm{~km}^{2}\right)$ is more appropriate. In other words, the WAVA vulnerability map is no substitute for site specific hydrogeological investigation.

The relative vulnerability zones delineated in this report may be applied to facilitate designation of "protection zones" by regulatory agencies. These "protection zones," however, would likely include other factors affecting the hydrologic system, including ground-water flow gradients and proximity to impacted areas. The WAVA vulnerability map can also be used to develop measures designed to protect the Floridan Aquifer System, which provides flow to the Wekiva River and Wekiwa Spring. The model results have far reaching implications and can be applied to a variety of environmental management, protection and conservation activities, including:

- Wellhead protection

- $\quad$ Source-water protection

- Recharge protection 


\section{FLORIDA GEOLOGICAL SURVEY}

- Vulnerability indices

- Contaminant-specific maps

- Land conservation acquisition

- Total maximum daily loads (TMDLs)

- $\quad$ Surface-water/ground-water interactions

- Water-quality management tool

- Resource planning strategies and policies

- Prioritization of areas of critical concern

- Design of monitoring plans

- Best Management Practices

The results of the WAVA vulnerability model are useful for development and implementation of groundwater protection measures; however, the vulnerability output map included in this report should not be viewed as a static evaluation of the vulnerability of the Floridan Aquifer System. The model was built using the best data available at the time this project was completed and as a result, represents a "snapshot" in time. As new and more refined data become available for the WAVA study area, this data can be incorporated into future modeling scenarios. The advantages of including new or enhanced data include a more refined output vulnerability map with higher confidence in the results. Data improvements could include input of detailed topographic data (i.e., LIDAR), collection of soil permeability data for the "no data" areas along the Seminole-Orange County border (Figure 17) or strategically collecting water-level data to improve the hydraulic head difference evidential theme. Enhancement of these data layers would yield significant improvements in refinement, accuracy and statistical confidence of the final model output. The more fine-tuned the input data, the more detailed and reliable the model results can be. The weights of evidence modeling approach to aquifer vulnerability is a highly adaptable and useful tool for implementing ongoing protection of Florida's vulnerable ground-water resources.

\section{Disclaimer}

The WAVA map was developed by the FDEP/FGS to carry out agency responsibilities related to management, protection, and responsible development of Florida's natural resources. Although efforts have been made to make the information in these maps accurate and useful, the FDEP/FGS assumes no responsibility for errors in the information and does not guarantee that the data are free from errors or inaccuracies. Similarly FDEP/FGS assumes no responsibility for the consequences of inappropriate uses or interpretations of the data on these maps. As such, these maps are distributed on an "as is" basis and the user assumes all risk as to their quality, the results obtained from their use, and the performance of the data. FDEP/FGS further makes no warranties, either expressed or implied as to any other matter whatsoever, including, without limitation, the condition of the product, or its suitability for any particular purpose. The burden for determining suitability for use lies entirely with the user. In no event shall the FDEP/FGS have any liability whatsoever for payment of any consequential, incidental, indirect, special, or tort damages of any kind, including, but not limited to, any loss of profits arising out of use of or reliance on the maps or support by FDEP/FGS. FDEP/FGS bears no responsibility to inform users of any changes made to this data. Anyone using this data is advised that resolution implied by the data may far exceed actual accuracy and precision.

Comments on this data are invited and FDEP/FGS would appreciate that documented errors be brought to the attention of our staff. The development of these data sets represents a major investment of staff time, effort and funds. As a professional responsibility, we expect that the FDEP/FGS will receive proper credit when these data sets are used. Further, since part of this data was developed and collected with State of Florida funding, no proprietary rights may be attached to it in whole or in part, nor may it be sold to the U.S. Government or the Florida State Government as part of any procurement of products or services. 


\section{WEIGHTS OF EVIDENCE GLOSSARY}

Binary - Refers to the generalization or simplification of evidential themes or data layers. Binary layers are reclassified from the original dataset into presence/absence type themes or into two classes.

Conditional Independence - Occurs when an evidential theme does not affect the probability of another evidential theme. Evidential themes are considered independent of each other if the conditional independence value calculated is within the range $1.00 \pm 0.15$ (Raines, personal communication, 2003). Values that significantly deviate from this range can inflate the posterior probabilities resulting in unreliable response themes.

Confidence of evidential theme - Contrast divided by its estimated standard deviation; provides a useful measure of significance of the contrast.

Confidence of Posterior Probability - A measure based on the ratio of posterior probability to its estimated standard deviation.

Contrast - W+ minus W- (see weights), which is an overall measure of the spatial association (correlation) of an evidential theme with the training points.

Cumulative Ascending - Calculates the cumulative weights from the first class to the last class while increasing the area. Areas nearest a training point have a stronger association, and those farthest away have a weaker association. This method is applicable for themes where the training points are mainly associated with the lower values of the evidential theme (e.g., higher vulnerability correlates with lower confinement thickness).

Cumulative Descending - Calculates the cumulative weights from the last class to the first class while increasing the area (opposite of cumulative ascending). This method is applicable for themes where the training points are mainly associated with the higher values of the evidential theme (e.g., higher vulnerability correlates with higher soil permeability).

Evidential Theme - A set of continuous spatial data that is associated with the location and distribution of known occurrences (i.e., training points); these map data layers are used as predictors of vulnerability.

Kappa Coefficient - Allows statistical comparison of map patterns. It is a multivariate accuracy assessment technique developed by Cohen (1960) to determine if one error matrix is significantly different than another.

LIDAR - Light detection and ranging; an airborne remote sensing system that uses laser light to measure land-surface elevation with a high degree of accuracy and resolution. LIDAR data can be used to generate digital elevation models.

Model - The characteristics of a set of training points, and the relationships of the training points to a collection of evidential themes.

Posterior Probability - The probability that a unit cell contains a training point after consideration of the evidential themes. This measurement changes from location to location depending on the values of the evidence. 


\section{FLORIDA GEOLOGICAL SURVEY}

Prior Probability - The probability that a unit cell contains a training point before considering the evidential themes. It is a constant value over the study area equal to the training point density (total number of training points divided by total study area in unit cells).

Response Theme - An output map that displays the probability that a unit area would contain a training point, estimated by the combined weights of the evidential themes. The output is displayed in classes of relative aquifer vulnerability or favorability to contamination (i.e., this area is more vulnerable than that area) or favorability. The response theme is the relative vulnerability map.

Spatial Data - Information about the location and shape of, and relationships among, geographic features, usually stored as coordinates and topology.

Study Area - A grid theme that acts as a mask to define the area where the model is developed and applied. It may be irregular in outline and may contain interior holes (e.g., lakes and no data areas).

Training Points - A set of locations (points) reflecting a parameter used to calculate weights for each evidential theme, one weight per class, using the overlap relationships between points and the various classes. In an aquifer vulnerability assessment, training points are wells with one or more water quality parameters indicative of relatively higher recharge which is an estimate of relative vulnerability.

Weights - A measure of an evidential-theme class. A weight is calculated for each theme class. For binary themes, these are often labeled as $\mathrm{W}+$ and $\mathrm{W}-$. For multiclass themes, each class can also be described by a $\mathrm{W}+$ and $\mathrm{W}$ - pair, assuming presence/absence of this class versus all other classes. Positive weights indicate that more points occur on the class than due to chance, and the inverse for negative weights. The weight for missing data is zero. Weights are approximately equal to the proportion of training points on a theme class divided by the proportion of the study area occupied by theme class, approaching this value for an infinitely small unit cell. 


\section{REFERENCES}

Arthur, J.D., Baker, A.E., Cichon, J.R., Wood, H.A.R., and Rudin, A., 2005, in preparation, Florida Aquifer Vulnerability Assessment (FAVA): Contamination potential of Florida's principal aquifer systems: Florida Geological Survey Bulletin 67.

Baker, A.E., Wood, A.R., Cichon, J.R., and Arthur, J.D., 2005, Alachua Aquifer Vulnerability Assessment; a final report submitted to Alachua County, January, 2005, 36 p. (unpublished).

Berndt., M.P., Oaksford, E.T., Mahon, G.L., and Schmidt., W., 1998, Groundwater, in Fernald, E.A., and Purdum, E. D., eds., Water Resources Atlas of Florida: Florida State University, Institute of Public Affairs, 312 p.

Bonham-Carter, G. F., 1994, Geographic Information Systems for Geoscientists, Modeling with GIS: Oxford, Pergamon, 398 p.

Cichon, J.R., Wood, H.A.R., Baker, A.E., and Arthur, J.A., 2004, Application of Geologic Mapping and Geographic Information Systems to Delineate Sensitive Karst Areas for Land-Use Decisions: American Geological Institute website, http://www.agiweb.org/environment/publications/ mapping/graphics/florida.pdf, 2004.

Cohen, J., 1960, A coefficient of agreement for nominal scales: Educational and Psychological Measurement, v. 20, no. 1, p. 37-46.

Davis, J., Johnson, R., Boniol, D., and Rupert, F., 2001, Guidebook to the Correlation of Geophysical Well Logs within the St. Johns River Water Management District: Florida Geological Survey Special Publication No. 50, 114 p.

Florida Geographic Data Library, 2003, GeoPlan Center, Gainesville, University of Florida: www.fgdl.org/.

Kemp, L.D., Bonham-Carter, G.F., Raines, G.L. and Looney, C.G., 2001, Arc-SDM: Arcview extension for spatial data modeling using weights of evidence, logistic regression, fuzzy logic and neural network analysis: http://ntserv.gis.nrcan.gc.ca/sdm/, 2002.

Landis, J.R. and Koch, G.G., 1977, The measurement of observer agreement for categorical data: Biometrics, v. 33, p. 159-174.

National Research Council, 1993, Ground Water Vulnerability Assessment: Predicting Relative Contamination Potential under Conditions of Uncertainty: Washington, National Academy Press, 204 p.

Raines, Gary L., 1999, Evaluation of Weights of Evidence to Predict Epithermal-Gold Deposits in the Great Basin of the Western United States: Natural Resources Research, v. 8, no. 4, p. 257-276.

Raines, G. L., Bonham-Carter, G. F., and Kemp, L., 2000, Predictive Probabilistic Modeling Using ArcView GIS: ArcUser, v. 3, no.2, p. 45-48. 


\section{FLORIDA GEOLOGICAL SURVEY}

Scott, T.M., Means, G.H., Meegan, R.P., Means, R.C., Upchurch, S.B., Copeland, R.E., Jones, J., Roberts, T., and Willet, A., 2004, Springs of Florida: Florida Geological Survey Bulletin No. 66, 377 p.

Sepulveda, N., 2002, Simulation of Ground-Water Flow in the Intermediate and Floridan Aquifer Systems in Peninsular Florida: U.S. Geological Survey Water-Resource Investigation Report 024009, $130 \mathrm{p}$.

Southeastern Geological Society Ad Hoc Committee, 1986, Hydrogeological Units of Florida: Florida Geological Survey Special Publication No. 28, 8 p.

U.S. Census Bureau: State and County Quick Facts, 01-Feb-2005, 15:48:47 EST: www.census.gov.

Wekiva River Basin Coordinating Committee, 2004, Wekiva River Basin Coordinating Committee Final Report: Recommendations for Enhanced Land Use Planning Strategies and Development Standards to Protect Water Resources of the Wekiva River Basin, March 16, 2004, 50 p. (unpublished).

Wright, A.P., 1974, Environmental Geology and Hydrology of the Tampa Area, Florida: Florida Geological Survey Special Publication No. 19, 93 p. 